\title{
TISSUE PLASMINOGEN ACTIVATOR AND UROKINASE PLASMINOGEN ACTIVATOR IN HUMAN EPILEPTOGENIC PATHOLOGIES
}

\author{
A. M. IYER, ${ }^{a 1}$ E. ZUROLO, ${ }^{a 1}$ K. BOER, ${ }^{\text {a }}$ J. C. BAAYEN, ${ }^{b}$ \\ F. GIANGASPERO, ${ }^{c, d}$ A. ARCELLA, ${ }^{d}$ \\ G. C. DI GENNARO, d V. ESPOSITO, ${ }^{\mathrm{d}, \mathrm{e}}$ W. G. M. SPLIET, ${ }^{\mathrm{f}}$ \\ P. C. VAN RIJEN, ${ }^{\mathrm{g}}$ D. TROOST, ${ }^{\mathrm{a}}$ J. A. GORTER ${ }^{\mathrm{h}, \mathrm{i}}$ AND \\ E. ARONICA ${ }^{\mathrm{a}, \mathrm{i} *}$ \\ ${ }^{a}$ Department of (Neuro) Pathology, Academic Medical Center, Univer- \\ sity of Amsterdam, The Netherlands \\ ${ }^{b}$ Department of Neurosurgery, VU University Medical Center, Amster- \\ dam, The Netherlands \\ 'Department of Experimental Pathology, University Sapienza, Rome, \\ Italy \\ 'IRCCS Neuromed, Pozzilli, Isernia, Italy

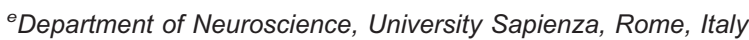 \\ ${ }^{f}$ Department of Pathology, Rudolf Magnus Institute for Neuroscience, \\ University Medical Center Utrecht, The Netherlands \\ ${ }^{g}$ Department of Neurosurgery, Rudolf Magnus Institute for Neuro- \\ science, University Medical Center Utrecht, The Netherlands

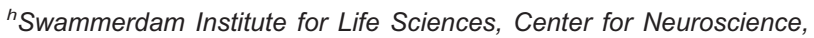 \\ University of Amsterdam, The Netherlands \\ 'Epilepsy Institute in The Netherlands Foundation (Stichting Epilepsie \\ Instellingen Nederland, SEIN), Heemstede, The Netherlands
}

\begin{abstract}
A growing body of evidence demonstrates the involvement of plasminogen activators (PAs) in a number of physiologic and pathologic events in the CNS. Induction of both tissue plasminogen activator (TPA) and urokinase plasminogen activator (UPA) has been observed in different experimental models of epilepsy and tPA has been implicated in the mechanisms underlying seizure activity. We investigated the expression and the cellular distribution of tPA and UPA in several epileptogenic pathologies, including hippocampal sclerosis (HS; $n=6$ ), and developmental glioneuronal lesions, such as focal cortical dysplasia (FCD, $n=6)$, cortical tubers in patients with the tuberous sclerosis complex (TSC; $n=6$ ) and in gangliogliomas (GG; $n=6$ ), using immuno-cytochemical, western blot and real-time quantitative PCR analysis. TPA and UPA immunostaining showed increased expression within the epileptogenic lesions compared to control specimens in both glial and neuronal cells (hippocampal neurons in HS and dysplastic neurons in FCD, TSC and GG specimens). Confocal laser scanning microscopy confirmed expression of both proteins in astrocytes and microglia, as well as in microvascular endothelium. Immu-

${ }^{1}$ The first two authors contributed equally to the present work.

${ }^{*}$ Correspondence to: E. Aronica, Department of (Neuro) Pathology, Academic Medical Center, Meibergdreef 9, 1105 AZ Amsterdam, The Netherlands. Tel: +31-20-5662943; fax: +31-20-5669522.

E-mail address: e.aronica@amc.uva.nl (E. Aronica).

Abbreviations: DG, dentate gyrus; FCD, focal cortical dysplasia; GFAP, glial fibrillary acidic protein; GG, ganglioglioma; HS, hippocampal sclerosis; IR, immunoreactivity; MCD, malformations of cortical development; NMDA, N-methyl-D-asparte; PAl1, plasminogen activator inhibitor type-1; PAs, plasminogen activators; SE, status epilepticus; TBP, TATA-binding protein; TLE, temporal lobe epilepsy; tPA, tissue-type plasminogen activator; TSC, tuberous sclerosis complex; UPA, urokinase-type plasminogen activator.
\end{abstract}

noblot demonstrated also up-regulation of the UPA receptor (uPAR; $P<0.05$ ). Increased expression of tPA, UPA, UPAR and tissue PA inhibitor type mRNA levels was also detected by PCR analysis in different epileptogenic pathologies $(P<0.05)$. Our data support the role of PA system components in different human focal epileptogenic pathologies, which may critically influence neuronal activity, inflammatory response, as well as contributing to the complex remodeling of the neuronal networks occurring in epileptogenic lesions. () 2010 IBRO. Published by Elsevier Ltd. All rights reserved.

Key words: hippocampal sclerosis, focal cortical dysplasia, tuberous sclerosis, ganglioglioma, epilepsy.

The plasminogen (fibrinolytic) system comprises the inactive proenzyme, plasminogen, that can be converted to the active enzyme plasmin by two serine proteases, the tissue-type plasminogen activator (tPA) and the urokinase-type plasminogen activator (UPA) (Collen, 1999). TPA and UPA elicit various cellular responses, involving the activation of distinct signaling pathways. While several of these pathways have been described (Maupas-Schwalm et al., 2004; Benarroch, 2007), their interactions and the link to specific biological responses are only partly understood. Attention has been recently focused on the role of UPA receptor (UPAR) indicating that it may act as signaling receptor, also independently of uPA-mediated proteolysis (for review see Smith and Marshall, 2010). In the CNS, increasing evidence suggests a crucial role of the plasminogen system in a broad range of physiological and pathological processes ranging from neuronal development, cell migration and invasion, cell growth and apoptosis, immune responses, inflammation, angiogenesis and regulation of synaptic remodeling and neuronal plasticity (Seeds et al., 1999; Tsirka, 2002; Powell et al., 2003; Alfano et al., 2005; Benarroch, 2007).

TPA is widely expressed by many types of neurons in the human CNS, including the neocortical and hippocampal pyramidal neurons (Teesalu et al., 2004). Activation of the plasminogen system, involving neurons, reactive glial cells and vascular endothelium, as source of plasminogen activators, has been reported in different neurological disorders such as stroke and other forms of acute brain injury, as well as in patients with inflammatory disorders (Gveric et al., 2001; Teesalu et al., 2002; Benarroch, 2007). A complex deregulation of the plasminogen system may also be involved in neurodegenerative disorders, such as Alzheimer's disease (Tucker et al., 2002; Fabbro and Seeds, 2009).

Several experimental findings identified a role for IPA in the mechanisms underlying seizure activity (Tsirka et al., 1995; Pawlak and Strickland, 2002; Benarroch, 2007). Interestingly, induction of plasminogen activators (PAs) has been

0306-4522/10 \$ - see front matter @ 2010 IBRO. Published by Elsevier Ltd. All rights reserved.

doi:10.1016/j.neuroscience.2010.02.047 
Table 1. Summary of clinical details of cases studied according to pathology

\begin{tabular}{|c|c|c|c|c|}
\hline Pathology type (pm or s) & Number of cases & Mean age at surgery (range/y) & Localization & Mean duration of epilepsy (range/y) \\
\hline $\mathrm{HS}(\mathrm{pm})$ & 6 & $26.3(12-42)$ & Temporal & $17(11-32)$ \\
\hline Non-HS (s) & 5 & $29.5(18-41)$ & Temporal & $15.2(6-22)$ \\
\hline FCD IIB (s) & 6 & $27.3(14-48)$ & $\begin{array}{l}\text { Temporal (4) } \\
\text { Frontal (2) }\end{array}$ & $19.2(5-25)$ \\
\hline Cortical tubers (TSC; s) & 6 & $17.8(5-35)$ & $\begin{array}{l}\text { Frontal (3) } \\
\text { Temporal (2) } \\
\text { Parietal (1) }\end{array}$ & $13.5(2.8-34)$ \\
\hline Ganglioglioma (GG; s) & 6 & $32(16-49)$ & Temporal & $16.1(12-26)$ \\
\hline Control neocortex (pm) & 6 & $31.6(18-35)$ & Temporal & - \\
\hline
\end{tabular}

HS, Hippocampal Sclerosis; FCD, Focal Cortical Dysplasia; TSC, Tuberous Sclerosis; pm, post-mortem; s, surgical specimens.

observed in different experimental models of epilepsy (Lukasiuk et al., 2003; Gorter et al., 2006; Lahtinen et al., 2006) and gene expression profile analysis of gangliogliomas (GG) revealed that both IPA and UPA represent one of the most up-regulated genes in these epileptogenic lesions (Aronica et al., 2008). In rat hippocampus, tPA and uPA were both activated at one day after induction of status epilepticus (SE) and were still elevated during epileptogenesis (Gorter et al., 2006, 2007; Lahtinen et al., 2006). Expression of tPA mRNA was still increased in the chronic phase in the CA3 region (Gorter et al., 2007). Recently, the cellular distribution of UPA and UPAR has been characterized in rat hippocampus during epileptogenesis (Lahtinen et al., 2006). However, whether the up-regulation of plasminogen activator proteins persists in the chronic phase in epileptic human brain is unclear. Moreover, a detailed analysis of IPA and UPA cellular expression in human epileptogenic pathologies is still lacking. Because of the functional redundancy among PAs (Carmeliet and Collen, 1995), characterization of the expression in human tissue is important for the correct interpretation of the experimental observations.

In the present study we have examined the tPA and uPA tissue distribution, evaluated their degree of expression and defined their cellular origin in common causes of human focal chronic refractory epilepsy.

\section{EXPERIMENTAL PROCEDURES}

\section{Subjects}

The human cases included in this study were obtained from the files of the departments of neuropathology of the Academic Medical Center (AMC, University of Amsterdam), the VU University Medical Center (VUMC) in Amsterdam, the University Medical Center in Utrecht (UMC) and the Neuromed Neurosurgery Center for Epilepsy, Pozzilli-Isernia, Italy. We examined a total of 29 surgical epilepsy specimens, six hippocampal sclerosis (HS), five hippocampal surgical specimens of patients without HS (non-HS; with a focal lesion not involving the hippocampus proper; no appreciable neuronal loss and reactive gliosis are observed in the hippocampus), six focal cortical dysplasia (FCD) type IIB, six cortical tubers from patients with Tuberous Sclerosis Complex (TSC), six ganglioglioma (GG). In six patients (two FCD, two GG and two TSC) a significant amount of perilesional tissue (normal-appearing cortex/white matter adjacent to the lesion) was resected as well. This material was carefully inspected by microscopy, using both histological and immunocytochemical stainings (HE, luxol-PAS, GFAP, vimentin, neurofilament, neuronal nuclear protein, NeuN and phosphorylated ribosomal pro- tein $\mathrm{S} 6$ and CD34) to differentiate the lesion (tumor or malformation) from the perilesional control cortex, defined as cortical region adjacent the lesion, but histologically normal (i.e. not containing tumor cells, dysplastic neurons and without appreciable neuronal loss and reactive gliosis). Informed consent was obtained for the use of brain tissue and for access to medical records for research purposes. Tissue was obtained and used in a manner compliant with the Declaration of Helsinki. The clinical characteristics derived from the patient's medical records are summarized in Table 1. Patients underwent therapeutic surgical resection for refractory epilepsy and had predominantly medically intractable complex partial seizures.

The HS specimens include four cases of classical HS (grade 3; Wyler et al., 1992; Mesial Temporal Sclerosis (MTS) type 1a; Blumcke et al., 2007) and two cases of severe HS (grade IV; Wyler et al., 1992; MTS type 1b; Blumcke et al., 2007). For the FCD we followed the classification system proposed by Palmini et al. for grading the degree of FCD (Palmini et al., 2004). All patients with cortical tubers fulfilled the diagnostic criteria for TSC (Gomez et al., 1999). For the GG we used the revised WHO classification of tumors of the CNS (Louis et al., 2007). The patients undergoing epilepsy surgery predominantly had medically intractable complex partial seizures. In addition, normal-appearing control cortex/white matter was obtained at autopsy from six young adult control patients (male/female: $3 / 3$; mean age 31 ; range 18-35), without a history of seizures or other neurological diseases. All autopsies were performed within $12 \mathrm{~h}$ after death.

\section{Human tissue preparation and immunocytochemistry}

The tissue was fixed in $10 \%$ buffered formalin (autopsy tissue, for 2 weeks; surgical specimens, for 24 hours). To detect differences in labeling related to technical variables such as tissue fixation, we also tested the antibodies in specimens of selected regions (temporal cortex/ hippocampus) collected at autopsy and immediately fixed in formalin for $24 \mathrm{~h}$ (same fixation time used for the surgical specimens). Formalin fixed, paraffin-embedded tissue was sectioned at 6 $\mu \mathrm{m}$ and mounted on organosilane-coated slides (SIGMA, St. Louis, MO, USA). Specimens were processed for haematoxylin/eosin and Nissl, as well as for immunocytochemical reactions.

Glial fibrillary acidic protein (GFAP; polyclonal rabbit, DAKO, Glostrup, Denmark; 1:4000), vimentin (mouse clone V9, DAKO; $1: 400$ ), neuronal nuclear protein (NeuN; mouse clone MAB377, IgG1; Chemicon, Temecula, CA, USA; 1:1000), neurofilament (NF, SMI311; Sternberger Monoclonals, Lutherville, MD; 1:1000), microtubule-associated protein (MAP2; mouse clone HM2; Sigma 1:100), (HLA)-DP, DQ, DR (mouse clone CR3/43; DAKO, Glostrup, Denmark, 1:400), CD68 (mouse clone PG-M1, DAKO; 1:200) and CD31 (mouse JC/70A; 1:100), were used in the routine immunocytochemical analysis of epilepsy specimens.

For the detection of IPA we used a mouse anti-human IPA (American Diagnostica Inc., Greenwich, CT, USA; 1:50; previously used and characterized; Teesalu et al., 2004), a rabbit 
anti-human tPA (Santa Cruz Bio., CA, USA; 1:50) and a rabbit anti-human tPA (1:100; kindly provided by Dr. Lijnen, Center for Molecular and Vascular Biology, Leuven, Belgium and previously characterized (Lijnen et al., 1988)). For the detection of uPA we used a mouse anti-human uPA (American Diagnostica Inc., Greenwich, CT, USA; 1:50; previously used and characterized; Schmitt et al., 1991; Wagner et al., 1996) and a rabbit anti-human uPA (1:500; provided by Dr. H.R. Lijnen and previously characterized; Lijnen et al., 1988). To evaluate the specificity of the staining the following control experiments were performed on paraffin-embedded human temporal cortex and hippocampal specimens: (1) omission of the primary antibody; (2) substitution of the primary antibody with a rabbit pre-immune or non-immune lgG or a monoclonal mouse IgG of irrelevant specificity; and (3) preadsorption of TPA and UPA polyclonal antibodies using an excess of tPA- and UPA antigen, or using the specific immunogen peptide for the anti-human IPA (from Santa Cruz Bio). These control experiments resulted in the absence of staining. Immunocytochemistry was carried out on paraffin-embedded tissue as previously described (Aronica et al., 2001b). Single-label immunocytochemistry was performed with Powervision (Immunologic, Duiven, The Netherlands). 3,3-Diaminobenzidine was used as chromogen. Sections were counterstained with Haematoxylin.

For double-labeling studies, sections, after incubation with primary antibodies, were incubated for $2 \mathrm{~h}$ at RT with Alexa Fluor ${ }^{\circledR} 568$ and Alexa Fluor ${ }^{\circledR} 488$ (anti-rabbit lgG or antimouse IgG; 1:200; Molecular probes, Eugene, USA). Sections were then analyzed by means of a laser scanning confocal microscope (Bio-Rad, Hercules, CA, USA; MRC1024) equipped with an argon-ion laser.

\section{Evaluation of immunostaining}

All labeled tissue sections were evaluated with respect to the presence or absence of various histopathological parameters and specific immunoreactivity (IR) for the different markers. The intensity of tPA and UPA staining was evaluated using a scale of $0-3$ (0: no; 1 : weak; 2 : moderate; 3 : strong staining). All areas of the specimen were examined and the score represents the predominant cell staining intensity found in each case for the different cell types (neurons, astrocytes, microglial cells and balloon cells). The frequency of tPA and UPA positive cells ((1) rare; (2) sparse; (3) high) was also evaluated to give information about the relative number of positive cells within the specimen. As proposed before (Vandeputte et al., 2002; Ravizza et al., 2006), the product of these two values (intensity and frequency scores) was taken to give the overall score (total score).

To analyze the percentage of GFAP or NeuN positive cells that express tPA or UPA within the epileptogenic lesions (HS, $n=5$; FCD, $n=5$ ) in each specimens two representative adjacent non-overlapping fields of the areas of interest (CA1, CA3 and hilar region for HS; dysplastic cortex for FCD) were captured (magnification 40×; total area of each field: $165.250 \mu \mathrm{m}^{2}$ ) and digitized using a laser scanning confocal microscope. The total number of cells stained with tPA (or UPA) and GFAP (or NeuN), as well as the number of double labelled cells were counted and percentages were calculated (expressed as mean \pm SEM) of cells coexpressing tPA (or UPA) and GFAP (or NeuN).

\section{Western blot analysis}

For immunoblot analysis, freshly frozen histologically normal autopsy hippocampus and cortex $(n=5)$, HS $(n=6)$, GG $(n=6)$ and FCD $(n=5)$ specimens; samples were homogenized in lysis buffer containing $10 \mathrm{mM}$ Tris (pH 8.0), $150 \mathrm{mM} \mathrm{NaCl}, 10 \%$ glycerol, $1 \% \mathrm{NP}-40$, Na-orthevanadate (10.4 mg/ml), $5 \mathrm{mM}$ EDTA (pH 8.0), $5 \mathrm{mM} \mathrm{NaF}$ and protease inhibitor cocktail (Boehringer Mannheim, Germany). Protein content was determined using the bicinchoninic acid method (Smith et al., 1985). For electrophoresis, equal amounts of proteins
(30 $\mu \mathrm{g} / \mathrm{lane}$ ) were separated by sodium dodecylsulfate-polyacrylamide gel electrophoretic (SDS-PAGE) analysis. Separated proteins were transferred to nitrocellulose paper for $1 \mathrm{~h}$ and $30 \mathrm{~min}$, using a semi-dry electroblotting system (BioRad, Transblot SD, Hercules, CA, USA). Blots were incubated over night in TTBS (20 mM Tris, 150 $\mathrm{mM} \mathrm{NaCl}, 0.1 \%$ Tween, $\mathrm{pH} 7.5) / 5 \%$ non fat dry milk, containing the primary antibody (tPA, rabbit anti-human, 1:1000, provided by Dr. H.R. Lijnen; uPA mouse anti-human, 1:500, American Diagnostica Inc; UPA receptor (UPAR), 1:5000, American Diagnostica Inc., using for UPAR non-reducing conditions). After several washes in TTBS, the membranes were incubated in TTBS $/ 5 \%$ non fat dry milk $/ 1 \%$ BSA, containing the goat anti-rabbit or goat anti-mouse antibodies coupled to horse radish peroxidase (1:2500; Dako, Denmark) for $1 \mathrm{~h}$. After washes in TTBS, immunoreactivity was visualized using Lumilight PLUS western blotting substrate (Roche Diagnostics, Mannheim, Germany) and digitized using a Luminescent Image Analyzer (LAS-3000, Fuji Film, Japan). Expression of $\beta$-actin (monoclonal mouse, Sigma, St. Louis, MO, USA 1:50.000) was used as reference protein.

\section{RNA isolation and real-time quantitative PCR analysis (RT-PCR)}

For RNA isolation, frozen material was homogenized in Trizol LS Reagent (Invitrogen, Carlsbad, CA, USA). After addition of $200 \mu \mathrm{g}$ glycogen and $200 \mu \mathrm{l}$ chloroform, the aqueous phase was isolated using Phase Lock tubes (Eppendorf, Hamburg, Germany). The concentration and purity of RNA were determined spectrophotometrically at $260 / 280 \mathrm{~nm}$ using a nanodrop spectrophotometer (Ocean Optics, Dunedin, FL, USA). Five micrograms of total RNA were reverse-transcribed into cDNA using oligo dT primers as described previously (Aronica et al., 2004). Specific primers were designed for the genes of interest using the Universal ProbeLibrary of Roche (https://www.roche-applied-science.com) on the basis of the reported cDNA sequences.

The following primers were used: TATA-binding protein (TBP; forward: caggagccaagagtgaagaac; reverse: aggaaataactctggctcataactact), tPA (forward: cgggtggaatattgctggt; reverse: cccgttgaaacaccttgg), uPA (forward: ttgctcaccacaacgacatt; reverse: ggcaggcagatggtctgtat), uPAR (forward: acaccaccaaatgcaacga; reverse: ccccttgcagctgtaacac) and the plasminogen activator inhibitor type-1 (PAl1; forward: tccagcagctgaattcctg; reverse: gctggagacatctgcatcct). For $1 \mu \mathrm{l}$ sample a Light Cycler SYBR green I master mix (Roche Applied Sciences, Indianapolis, IN, USA) was made containing in a total volume of $5 \mu \mathrm{l}: 0.2 \mu \mathrm{l}$ forward primer; $0.2 \mu \mathrm{l}$ reverse primer and $2.5 \mu \mathrm{l}$ master mix. A total of $6 \mu \mathrm{l}$ was run in duplicates in a 384 -well plate (Roche Applied Sciences, Indianapolis, IN, USA) in the LighCycler ${ }^{\circledR} 480$ Real-Time PCR System (Roche Applied Sciences, Indianapolis, IN, USA) under the following conditions: A 5 minute denaturing step at $95^{\circ} \mathrm{C}$ followed by a total of 45 amplification cycles consisting of 15 seconds denaturing at $95^{\circ} \mathrm{C}, 5$ seconds of annealing at $60{ }^{\circ} \mathrm{C}$ and 10 seconds of extension at $72{ }^{\circ} \mathrm{C}$. Fluorescent product was measured by a single acquisition mode at $72{ }^{\circ} \mathrm{C}$ after each cycle. Quantification of data was performed described previously (Aronica et al., 2008), using the computer program LinRegPCR in which linear regression on the Log (fluorescence) per cycle number data are applied to determine the amplification efficiency per sample (Ramakers et al., 2003). The starting concentration of each specific product was normalised to the amount of the reference gene TBP.

\section{Statistical analysis}

Statistical analyses were performed with SPSS for Windows (SPSS 11.5, SPSS Inc., Chicago, IL, USA) using two-tailed Student's $t$-test; to assess differences between more than two groups ANOVA and a non-parametric Kruskal-Wallis test followed by Mann-Whitney U-test. $P<0.05$ was considered significant. 


\section{RESULTS}

\section{TPA, UPA and uPAR protein expression}

Western blot analysis was performed to quantify the total amount of tPA, UPA and UPAR in total homogenates of HS specimens, compared to non-epileptic hippocampal tissue (autopsy material). The level of the tPA, UPA and UPAR protein expression was also analyzed in GG and FCD specimen and compared to non-epileptic control cortex. The UPAR antibody used for Western blot analysis did not work on paraffin-embedded tissue, therefore immunocytochemistry analysis of UPAR could not be performed.
Western blot analysis performed with tPA and uPA demonstrated a prominent band with a molecular weight of approximately 68 and $55 \mathrm{kDa}$, respectively in all tissue homogenate samples (Fig. 1A, B, D, E). Increased expression of both IPA and UPA was observed in HS, GG and FCD compared to control samples (Fig. 1A, B, D, E). Increased expression in the same pathologies compared to controls was also detected for uPAR (55 kDa, Fig. 1C, F). TPA, uPA and UPAR antibodies labeled additional bands of higher molecular weight (tPA and uPAR, $>200 \mathrm{kDa}$; uPA, approximately at $140 \mathrm{kDa}$ ) which corresponds to SDS-resistant complexes (Fig. 1A-C, panel c).

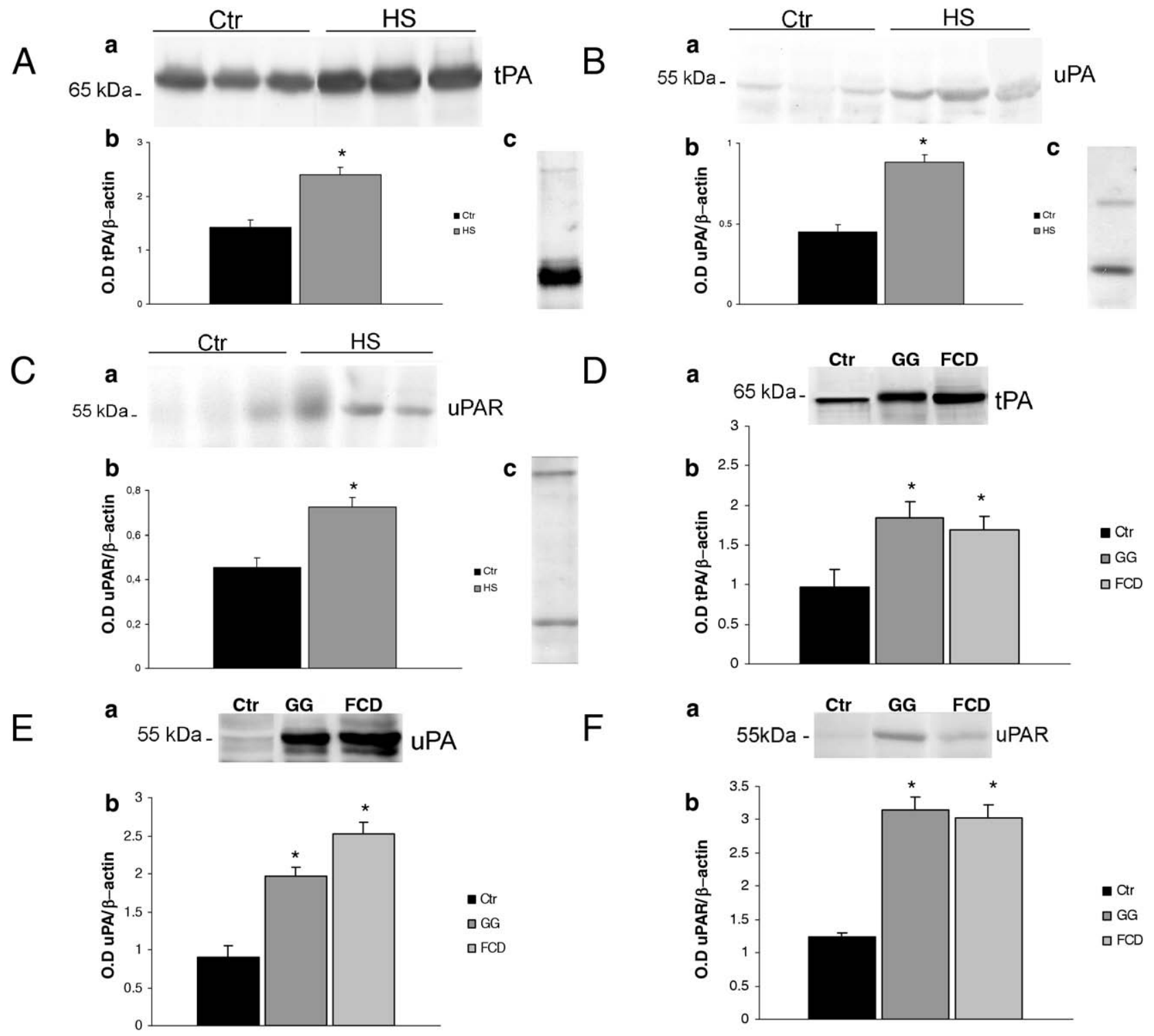

Fig. 1. Western blot analysis of tPA, UPA and UPAR (A-C): Representative immunoblots (a) and densitometric analysis (b) of total homogenates from control autopsy hippocampus (Ctr), and hippocampal sclerosis (HS) specimens. (D-F): Representative immunoblots (a) and densitometric analysis (b) of total homogenates from control autopsy cortex (Ctr), ganglioglioma (GG) and focal cortical dysplasia (FCD). Additional higher molecular weight bands detected with IPA, UPA and UPAR antibodies are shown in total homogenates of HS (tPA and uPAR, >200 kDa; uPA, $140 \mathrm{kDa}$; A-C, panel c). Densitometric analysis: values (optical density units, O.D.) are mean \pm SEM five controls (autopsy cortex and hippocampus) and six HS, six GG, five FCD relative to the optical density of $\beta$-actin; * $P<0.05$. 


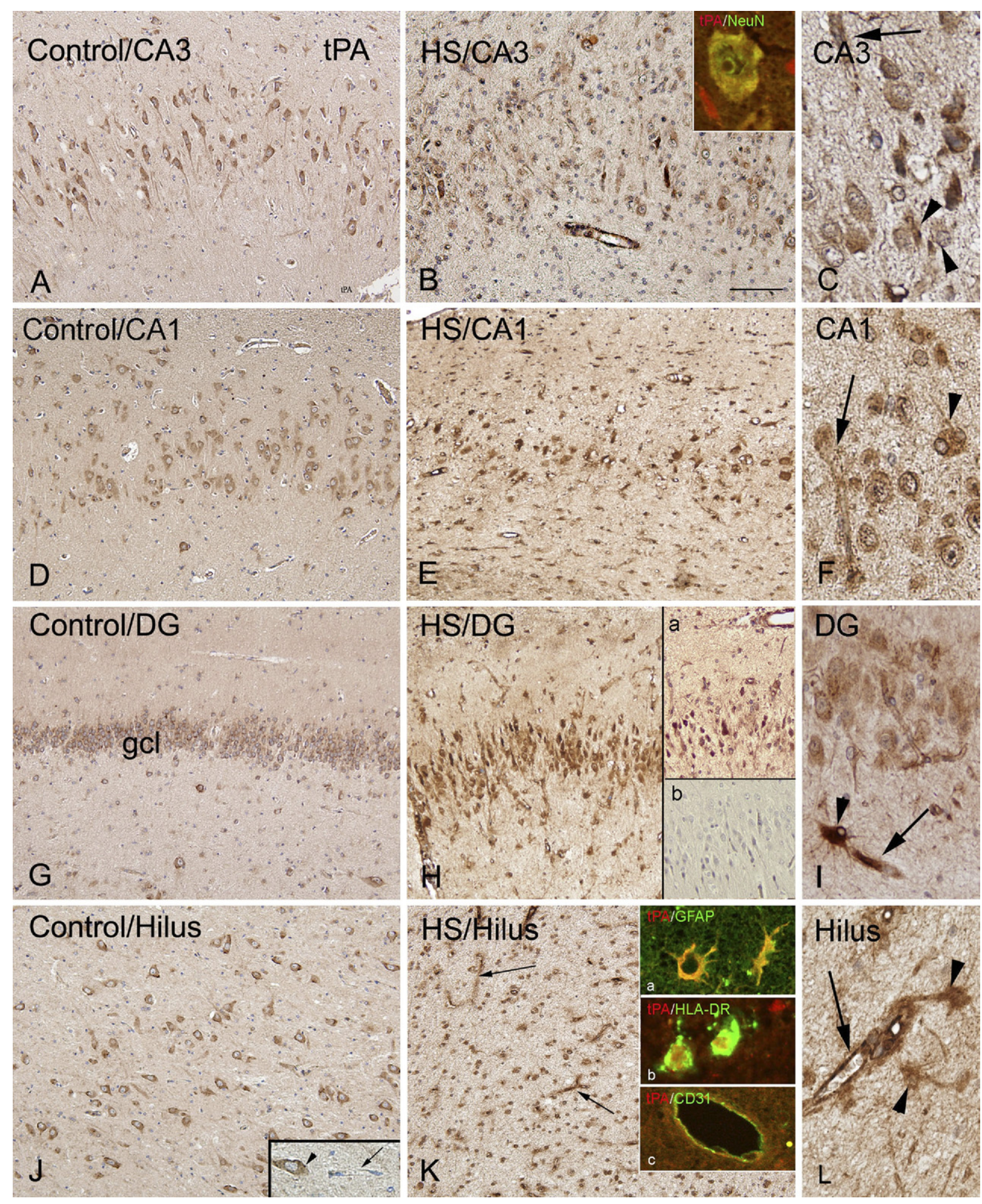

Fig. 2. Distribution of tPA immunoreactivity in the hippocampus of control and TLE patients with hippocampal sclerosis. Sections are counterstained with Hematoxylin. (A, D, G, J): Control autopsy hippocampus, showing neuronal immunoreactivity (IR) in the pyramidal neurons of CA3 (A), CA1 (D), granule cell layer and hilus of the dentate gyrus (DG, (G); hilus, (J)). (B, C), (E, F), (H, I), (K, L): Hippocampal sclerosis (HS), showing increased expression within the different hippocampal sub-regions (CA3, (B, C); CA1, (E, F); DG, (H, I), hilus, (K, L)). Expression is observed in both pyramidal neurons and granule cells of the DG, as well as in reactive glial cels (arrow-heads in C, F, I, L) and in blood vessels (arrows in C, F, K and L). Insert a in $(H)$ shows immunoreactivity in the DG obtained with mouse anti-human IPA; insert b in (H) shows absence of immunoreactivity after preadsorption with tPA. Insert in (B) shows co-localization (yellow) of tPA (red) with NeuN (green) in a pyramidal neuron. Insert (a) in (K) shows co-localization (yellow) of tPA (red) with GFAP (green) in reactive astrocytes; Insert (b) in (K) shows co-localization (yellow) of tPA (red) with HLA-DR (green) in cells of the microglia/macrophage lineage; Insert (c) in (K) shows co-localization (yellow) of tPA (red) with CD31 (green) in microvascular endothelium. Scale bar in (B). (A, B), (D, E), (G, H) and (J, K): $200 \mu \mathrm{m}$. (C, F, I, L): $60 \mu \mathrm{m}$. Granule cells layer (gcl); dentate gyrus (DG). For interpretation of the references to color in this figure legend, the reader is referred to the Web version of this article. 
A

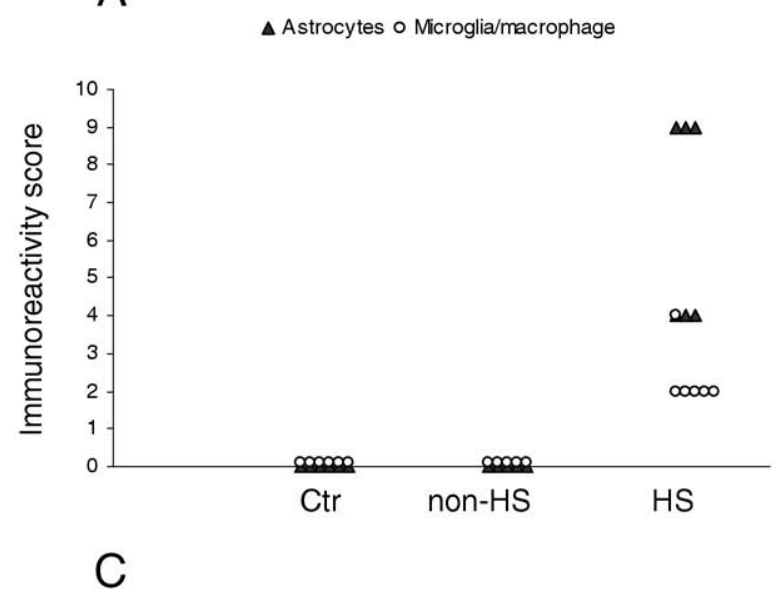

$\Delta$ Astrocytes o Microglia/macrophage

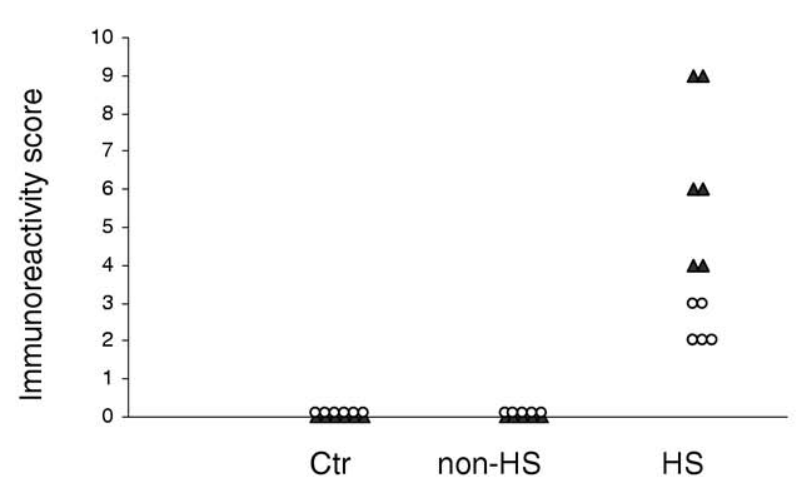

tPA

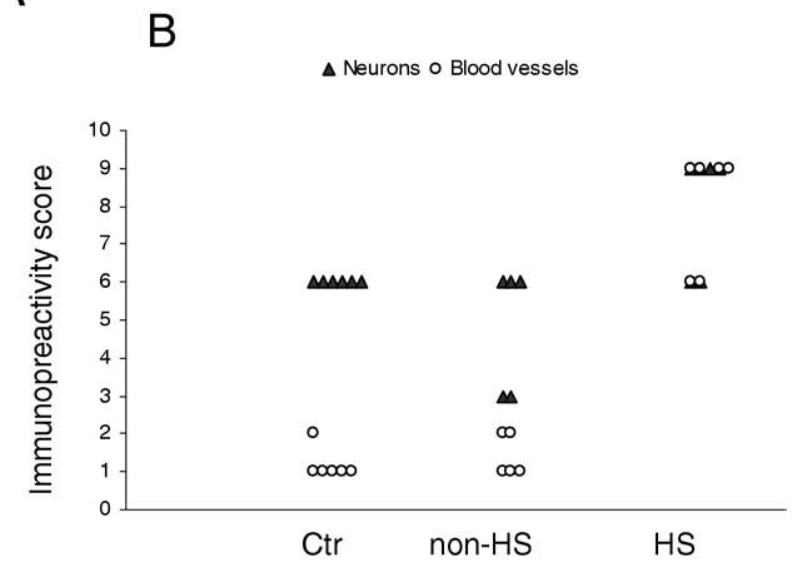

UPA

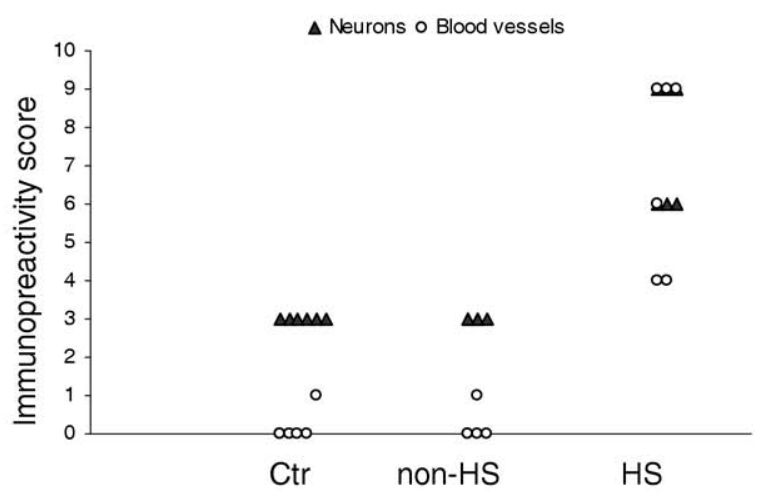

Fig. 3. Evaluation of tPA and UPA immunoreactivity (IR) in control hippocampus and in hippocampal sclerosis. Distribution of tPA and uPA IR scores (total score; see for details Methods section) in different cell types of normal control autopsy hippocampus (Ctr), control surgical hippocampus (non-hippocampal sclerosis, non-HS) and hippocampal sclerosis (HS). (A, B): tPA; (C, D): uPA; (A) and (C): astrocytes and microglia. (B) and (D): neurons and blood vessels.

\section{TPA IR in control hippocampus and in hippocampal sclerosis}

To evaluate the changes in expression and the cellular localization of tPA in the hippocampus of patients with temporal lobe epilepsy (TLE), immunocytochemical analysis was performed in surgical specimens of patients with HS and in surgical and autopsy specimens of histologically normal hippocampus. Three different antihuman tPA antibodies were used (see Experimental Procedures), with similar results; Fig. 2 shows the immunostaining performed with anti-tPA polyclonal antibody ((Lijnen et al., 1988); a representative microphotograph of the dentate gyrus (DG) in HS specimens stained with the monoclonal antibody against human tPA is shown in panel $\mathrm{H}$, insert a).

In agreement with previous observations in human tissue (Teesalu et al., 2004) in histologically normal hippocampus (autopsy and non-sclerotic hippocampus, non$H S$ ), tPA IR was mainly observed in neuronal cells, including pyramidal neurons of the different CA sub-fields, gran- ule cells of the DG and hilar neurons (Fig. 2A, D, J). As previously reported, neurons displayed a punctate cytoplasmic pattern of staining (Teesalu et al., 2004). Resting glial cells did not show detectable tPA IR and low expression was observed in endothelial cells of control hippocampal blood vessels (Figs. 2 and 3A, B).

In specimens from patients with HS increased expression of tPA was observed within the different hippocampal sub-fields (Fig. 2B, C, E, F, H, I, K, L). Strong tPA IR was detected in pyramidal neurons of CA1 and CA3 (Fig. 2B, C, $E, F)$, as well as in the granule cells of the dentate gyrus (Fig. $2 \mathrm{H}, \mathrm{I}$ ). In regions of prominent gliosis, reactive glial cells showed strong tPA IR (Figs. 2B, C, E, F, H, I, K, L and $3 A)$. In addition, increased expression of tPA IR was detected in the large majority of blood vessels within the hippocampus (Figs. 2B, C, E, F, H, I, K, L and 3B).

Double labelling experiments (performed with glial, neuronal and endothelial markers) confirmed the tPA expression in neurons (insert in Fig. 2B), GFAP-positive reactive astrocytes, HLA-DR-positive cells of the micro- 
glia/macrophage lineage and in endothelial cells (inserts in Fig. 2K).

The percentage of glial cells positive for TPA and coexpressing GFAP was quantified in CA1, CA3 and hilar region in five HS specimens $(84 \pm 5, \mathrm{CA} 1 ; 86 \pm 6, \mathrm{CA} 3$; $97 \pm 3$, hilus); the percentage of neuronal cells positive for tPA and co-expressing NeuN was quantified in CA1 and CA3 (98 \pm 3, CA1; $97 \pm 4$, CA3).

\section{TPA IR in control cortex and focal developmental lesions}

To evaluate the occurrence of changes in expression and cellular localization of tPA in focal malformations of cortical development (MCD), we studied tPA expression patterns in surgical specimens of patients with FCD (type IIB), cortical tubers (TSC), GG and in surgical and autopsy specimens of histologically normal cortex. Fig. 4 shows the immunostaining performed with anti-tPA polyclonal antibody (Lijnen et al., 1988).

Low tPA staining was observed within the normal cortex (autopsy material; Fig. 4A, B). The staining was localized in pyramidal neurons; resting glial cells did not show tPA IR and low expression was observed in blood vessels (and Fig. 5A, B). Histologically normal perilesional cortex displayed a pattern of IR similar to that observed in control autopsy cortex.

In FCD and TSC cases (Fig. 4C-E, FCD; Fig. 4F, TSC), intense tPA IR was observed throughout the dysplastic cortex. Staining was detected in dysplastic neurons, balloon and giant cells, reactive glial cells and in blood vessels (Figs. $4 \mathrm{C}-\mathrm{F}$ and $5 \mathrm{~A}, \mathrm{~B}$ ). Both the neuronal and glial components, as well as the blood vessels of $G G$ displayed tPA IR (Figs. 4G and 5A, B). Double labelling experiments (performed with glial, neuronal and endothelial markers in FCD, TSC and GG) confirmed the tPA expression in neurons, GFAP-positive cells, in endothelial cells (inserts in Fig. 4), as well as in HLA-DR-positive cells of the microglia/macrophage lineage (not shown).

The percentage of glial cells positive for tPA and co-expressing GFAP $(89 \pm 5)$ and neuronal cells co-expressing NeuN $(96 \pm 4)$ was quantified in five FCD specimens.

\section{UPA IR in control hippocampus and in hippocampal sclerosis}

To evaluate the changes in expression and the cellular localization of UPA in the hippocampus of patients with TLE, immunocytochemical analysis was performed in surgical specimens of patients with HS and in surgical and autopsy specimens of histologically normal hippocampus. Three different anti-human uPA antibodies were used (see Experimental Procedures), with similar results; Fig. 6 shows the immunostaining performed with anti-uPA polyclonal antibody (Lijnen et al., 1988); a representative microphotograph of the DG in HS specimens stained with the monoclonal antibody against human uPA is shown in panel $\mathrm{H}$, insert (a).

In agreement with previous observations in control rat hippocampus (Lahtinen et al., 2006), low uPA IR was detected in histologically normal human hippocampus (autopsy and non-sclerotic hippocampus, non-HS). The intensity of staining was light in CA1-3 pyramidal cells, as well as in granule cells of the DG and hilar neurons (Fig. 6A, D, G, J). Resting glial cells did not show detectable uPA IR and low expression was observed occasionally in endothelial cells (Figs. 6 and 3C, D).

In specimens from patients with HS increased expression of UPA was observed within the different hippocampal sub-fields (Fig. 6B, C, E, F, H, I, K, L). Strong uPA IR was detected in pyramidal neurons of CA1 and CA3 (Fig. 6B, C, $E, F)$, as well as in the granule cells of the dentate gyrus (Fig. $6 \mathrm{H}, \mathrm{I}$ ). In regions of prominent gliosis, reactive glial cells showed strong uPA IR (Figs. $6 \mathrm{~L}$ and $3 \mathrm{C}$ ). In addition, increased expression of UPA IR was detected in the large majority of blood vessels within the hippocampus (Figs. 6K and 3D).

Double labelling experiments (performed with glial, neuronal and endothelial markers) confirmed the UPA expression in neurons, GFAP-positive reactive astrocytes, HLA-DR-positive cells of the microglia/macrophage lineage and in endothelial cells (inserts in Fig. 6K).

The percentage of glial cells positive for UPA and coexpressing GFAP was quantified in CA1, CA3 and hilar region in five $\mathrm{HS}$ specimens $(74 \pm 2, \mathrm{CA} 1 ; 73 \pm 5, \mathrm{CA} 3$; $79 \pm 4$, hilus); the percentage of neuronal cells positive for UPA and co-expressing NeuN was quantified in CA1 and CA3 $(97 \pm 3, \mathrm{CA} 1 ; 98 \pm 2, \mathrm{CA} 3)$.

\section{UPA IR in control cortex and focal developmental lesions}

To evaluate the occurrence of changes in expression and cellular localization of UPA in focal malformations of cortical development, we studied uPA expression patterns in surgical specimens of patients with FCD (type IIB), cortical tubers (TSC), GG and in surgical and autopsy specimens of histologically normal cortex. Fig. 7 shows the immunostaining performed with anti-uPA polyclonal antibody (Lijnen et al., 1988).

Very low uPA staining was observed within the normal cortex (autopsy material; Fig. 7A, B). Occasionally scattered lightly labeled neurons were detected, but resting glial cells and blood vessels did not display detectable uPA IR (Figs. 7A, B and 5C, D). Histologically normal perilesional cortex displayed a pattern of IR similar to that observed in control autopsy cortex.

In FCD and TSC cases (Fig. 7C-E, FCD; Fig. 7F, TSC), intense uPA IR was observed throughout the dysplastic cortex. Staining was detected in dysplastic neurons, balloon and giant cells, reactive glial cells and in blood vessels (Figs. 7C-F and 5C, D). Both the neuronal and glial components, as well as the blood vessels of GG displayed UPA IR (Figs. $7 G$ and 5C, D). Double labelling experiments (performed with glial, neuronal and endothelial markers in FCD, TSC and GG) confirmed the uPA expression in neurons and GFAP-positive cells, in endothelial cells, as well as in HLA-DR- 


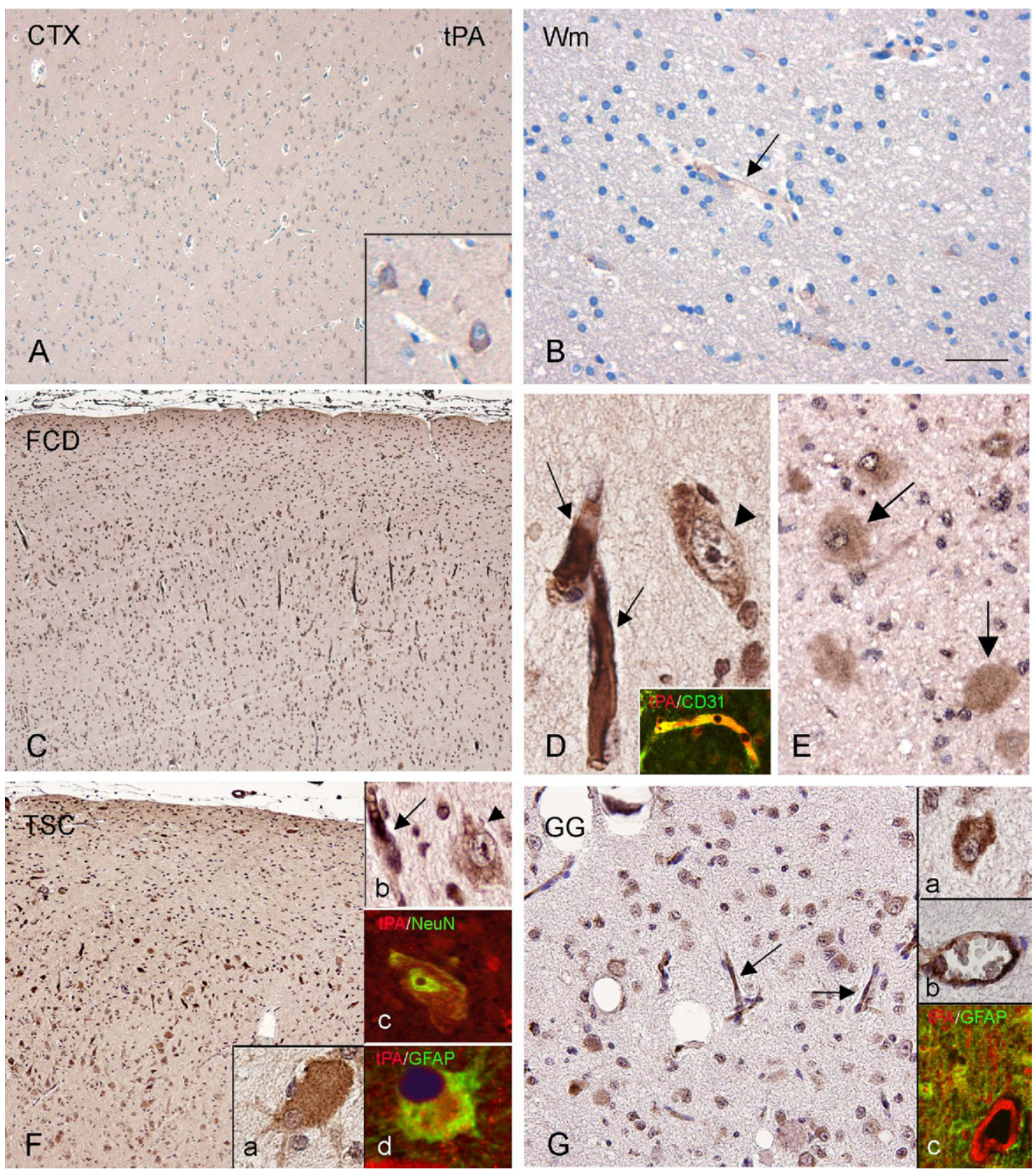

Fig. 4. Distribution of tPA immunoreactivity in control-cortex and malformations of cortical development. Sections are counterstained with Hematoxylin. Panels (A, B): tPA immunoreactivity (IR) in control autopsy cortex (A) and white matter (B) showing low expression in pyramidal neurons (A, insert in $A$ ) and in blood vessels (arrow in B), but no detectable glial labeling. Panels (C-E): tPA IR in focal cortical dysplasia (FCD) showing strong IR within the dysplastic cortex. High magnification photographs ( $D$ and $E$ ) show expression in dysplastic neurons (arrow-head in $D$ ) and in blood vessels (arrows in D), as well as in balloon cells (arrows in E). Insert in (D): co-localization (yellow) of tPA (red) with CD31 (green) in microvascular endothelium. Panel (F): tPA IR in cortical tuber of Tuberous Sclerosis Complex (TSC) showing strong expression within the dysplastic cortex. Insert (a) in (F): expression in a giant cell; insert (b) in (F): expression in dysplastic neurons (arrow-head) and in blood vessels (arrow). Insert (c) in (F): co-localization (yellow) of tPA (red) with NeuN (green) in a dysplastic neuron. Insert (d) in (F): co-localization (yellow) of tPA (red) with GFAP (green) in a reactive astrocyte. Panel (G): tPA IR in ganglioglioma (GG) showing expression in dysplastic neurons (insert a), blood vessels (arrows and insert b). Insert (c): co-localization (yellow) of tPA (red) with GFAP (green) in tumor astrocytes. Scale bar in B. (A, C, F): $400 \mu \mathrm{m}$. (B, E): $80 \mu \mathrm{m}$. (D): $30 \mu \mathrm{m} ;$ (G): $100 \mu \mathrm{m}$. For interpretation of the references to color in this figure legend, the reader is referred to the Web version of this article.

positive cells of the microglia/macrophage lineage and (inserts in Fig. 7).

The percentage of glial cells positive for UPA and coexpressing GFAP $(77 \pm 6)$ and neuronal cells co-expressing NeuN (82 \pm 4$)$ was quantified in five FCD specimens.

\section{Quantitative analysis of tPA, UPA, UPAR and PAI 1 mRNA expression}

Real-time quantitative PCR analysis was used to evaluate the level of TPA, UPA, UPAR and PAI1 in specimens 
A

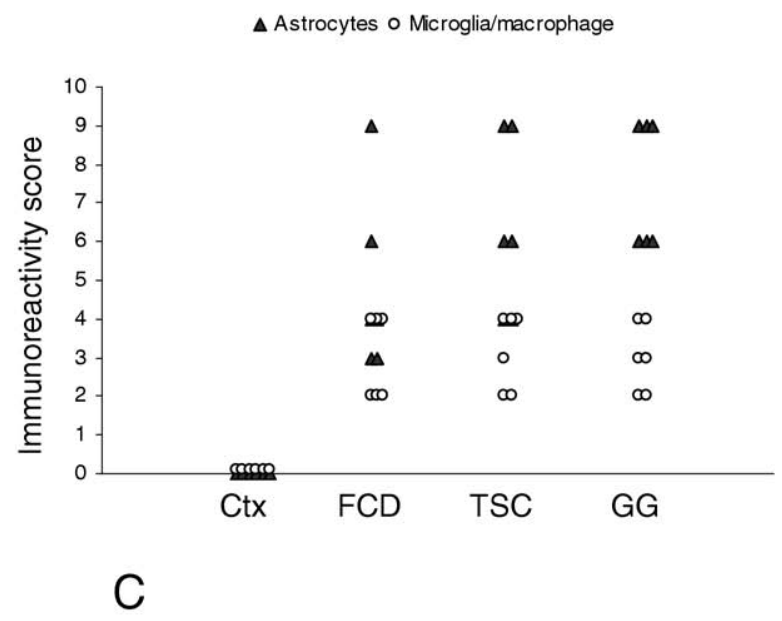

$\Delta$ Astrocytes o Microglia/macrophage

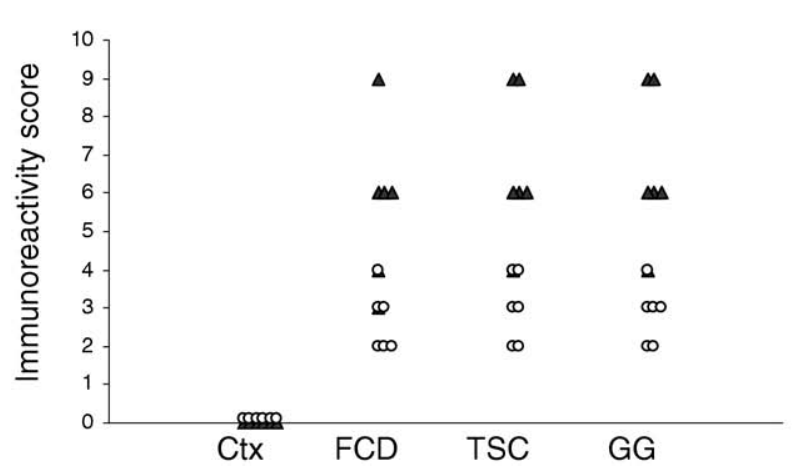

tPA

B
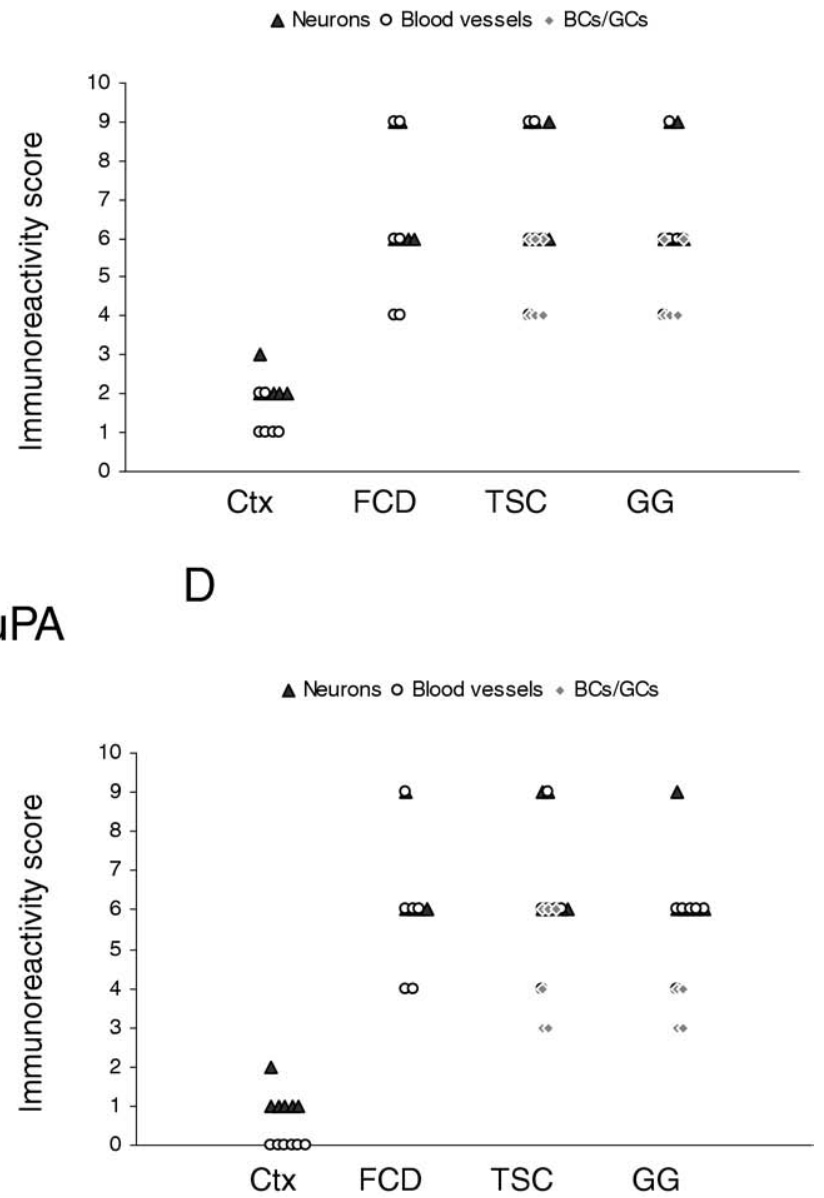

Fig. 5. Evaluation of tPA and UPA immunoreactivity (IR) in FCD, TSC and GG. Distribution of TPA and uPA IR scores (total score; see for details Methods section) in different cell types of normal control autopsy cortex (Ctx), focal cortical dysplasia (FCD), cortical tubers in patiens with Tubero Sclerosis Complex (TSC) and in gangliogliomas (GG). (A, B): tPA; (C, D): uPA; (A) and (C): astrocytes and microglia. (B) and (D): neurons, blood vessels and balloon/giant cells (BCs/GCs).

of patients with HS, GG and FCD. The expression of tPA mRNA was significantly up-regulated in GG (Fig. 8A), whereas UPA, UPAR and PAI1 were up-regulated in all the three pathologies analysed (HS, GG and FCD; Fig. 8B-D).

\section{DISCUSSION}

Data obtained in different experimental models suggest a critical role for the plasminogen system in the development of spontaneous seizures leading to a chronic epileptic condition (Pawlak and Strickland, 2002; Lukasiuk et al., 2003; Gorter et al., 2006; Lahtinen et al., 2006). The present study was designed to test the hypothesis that increased expression of TPA and UPA can be detected in common causes of human focal chronic refractory epilepsy.

According to previous observations in control rat and human hippocampus, the tPA protein is highly enriched in human CNS, particularly in the hippocampus (Teesalu et al., 2004; Lahtinen et al., 2006). The expression of
tPA (and to a lesser extent of UPA) in control tissue was mainly present in neuronal cells and, occasionally, in endothelial cells, whereas the resting glia did not express detectable levels of both proteins. This observation is in agreement with the neuronal mRNA distribution of tPA and UPA (Dent et al., 1993; Masos and Miskin, 1996; Teesalu et al., 2004). This cellular distribution supports the role of PAs in the regulation of synaptic activity under physiological conditions also in human brain (Tsirka, 2002; Benarroch, 2007).

\section{Hippocampal sclerosis and plasminogen activators}

HS, also known as Ammon's horn sclerosis, is the most common neuropathological finding in patients undergoing surgery for medically intractable TLE and is histopathologically characterized by selective neuronal cell loss and gliosis in CA1 and endfolium (Wieser, 2004). Material obtained from patients undergoing surgery for TLE with HS represents the end-stage of a long and complex process 


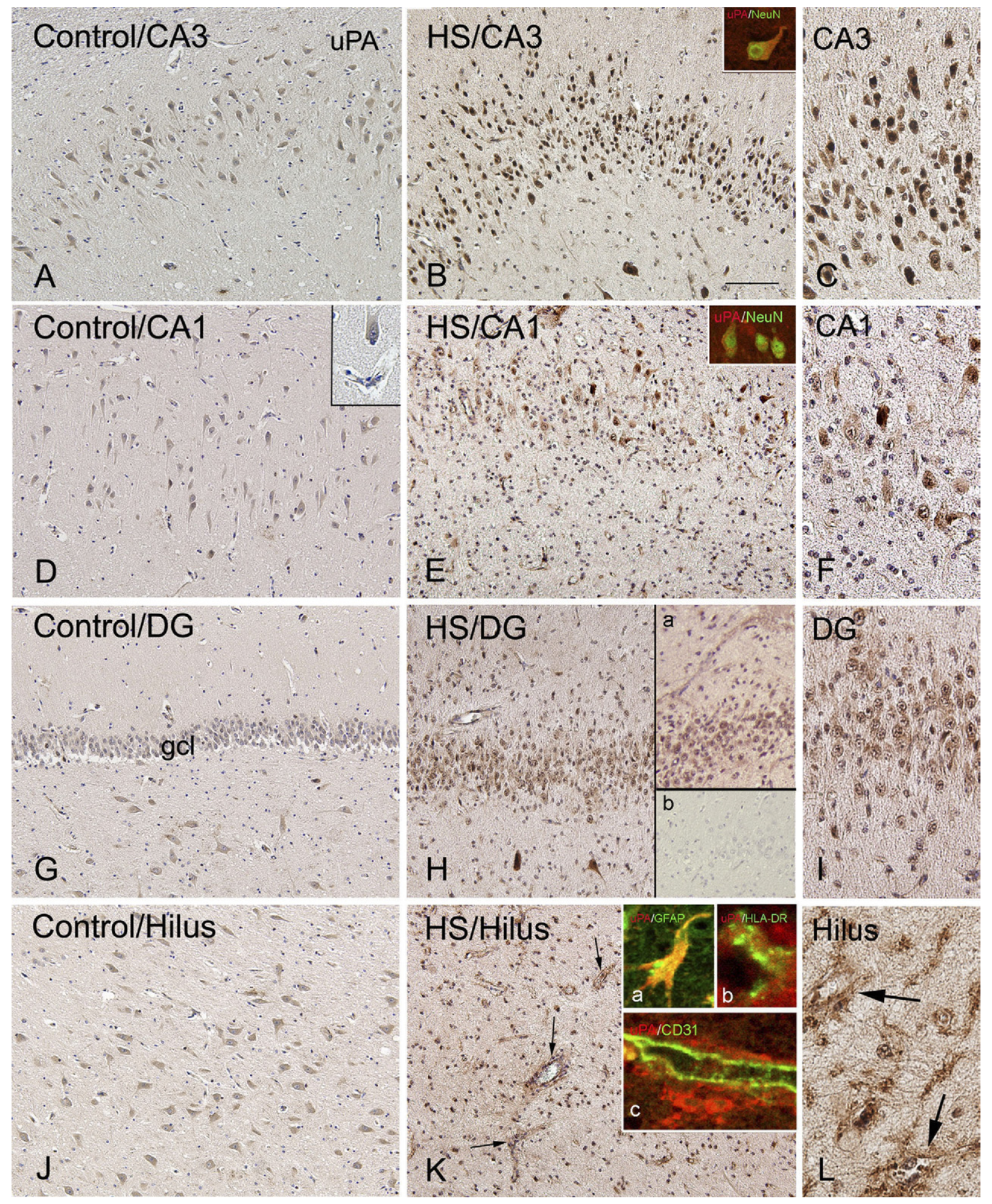

Fig. 6. Distribution of UPA immunoreactivity in the hippocampus of control and TLE patients with hippocampal sclerosis. Sections are counterstained with Hematoxylin. (A, D, G, J): Control autopsy hippocampus, showing weak neuronal immunoreactivity (IR) in the pyramidal neurons of CA3 (A), CA1 (D), granule cell layer and hilus of the dentate gyrus (DG, (G); hilus, (J)). Insert in (D): high magnification showing weak neuronal and endothelial IR in CA1. (B, C), (E, F), (H, I), (K, L): Hippocampal sclerosis (HS), showing increased expression within the different hippocampal sub-regions (CA3, $(B, C)$; $C A 1,(E, F)$; DG, (H, I); hilus, $(K, L))$. Arrows in (K) show IR in blood vessels; high magnification in (L) shows expression in perivascular glial cells (arrows). Insert (a) in (H) shows immunoreactivity in the DG obtained with mouse anti-human uPA; insert (b) in (H) shows absence of immunoreactivity after preadsorption with uPA. Inserts in (B) and (E): co-localization (yellow) of uPA (red) with NeuN (green) in a pyramidal neurons. Insert (a) in (K) shows co-localization (yellow) of UPA (red) with GFAP (green) in a reactive astrocyte; Insert (b) in (K) shows co-localization (yellow) of UPA (red) with HLA-DR (green) in cells of the microglia/macrophage lineage; Insert (c) in (K) shows co-localization (yellow) of uPA (red) with CD31 (green) in microvascular endothelium. Scale bar in B. (A, B), (D, E), (G, H) and (J, K): $200 \mu \mathrm{m}$. (C, F, I): $120 \mu \mathrm{m}$. (L): $60 \mu \mathrm{m}$. Granule cell layer (gcl); dentate gyrus (DG). For interpretation of the references to color in this figure legend, the reader is referred to the Web version of this article. 

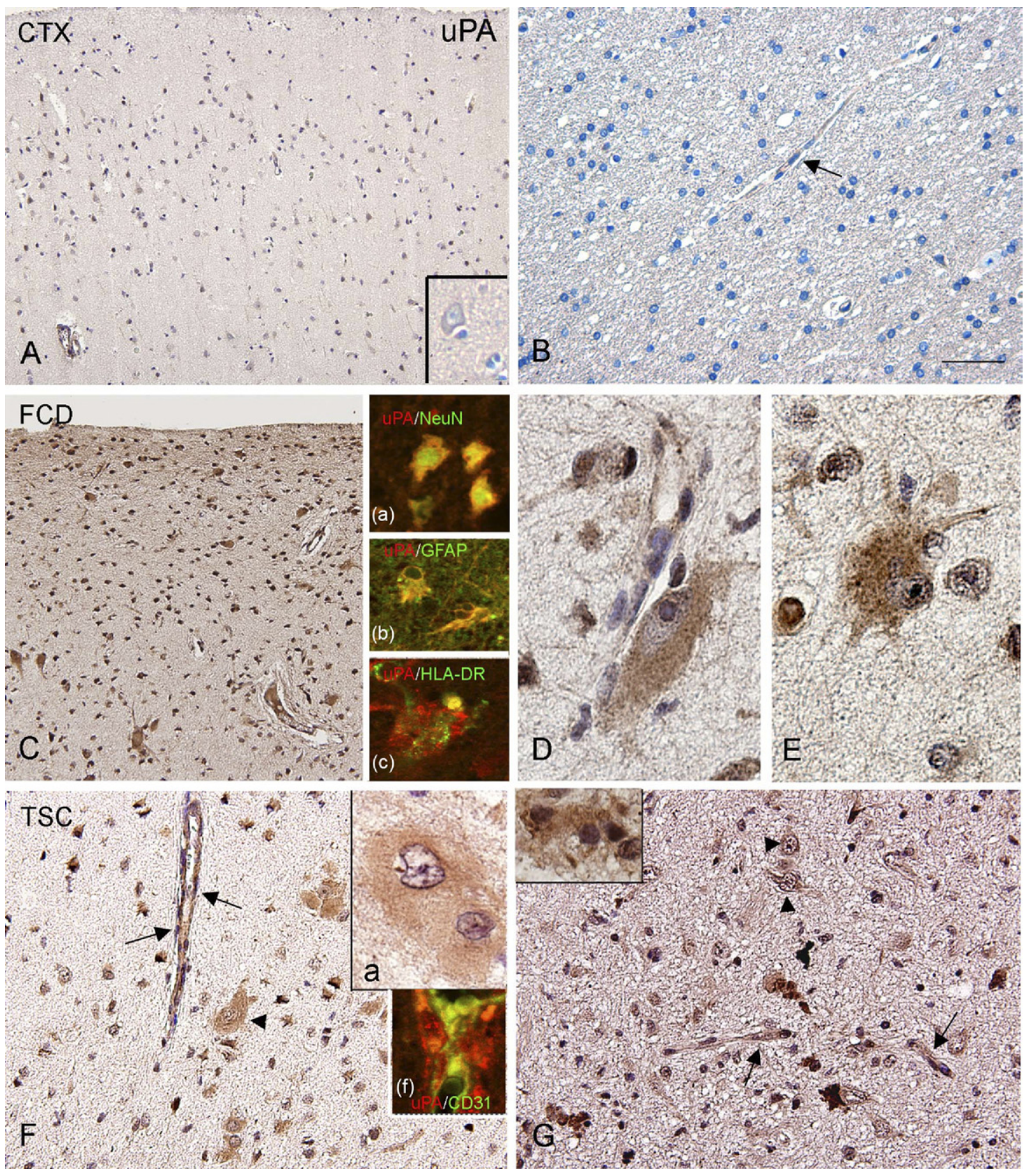

Fig. 7. Distribution of UPA immunoreactivity in control-cortex and malformations of cortical development. Sections are counterstained with Hematoxylin. Panels (A, B): UPA immunoreactivity (IR) in control autopsy cortex (A) and white matter (B) showing low expression in pyramidal neurons (A, insert in $A$ ) and no detectable expression in blood vessels (arrow in B) or in glial cells. Panels (C-E): uPA IR in focal cortical dysplasia (FCD) showing strong IR within the dysplastic cortex. High magnification photographs (D and $E)$ show expression in dysplastic neurons (D) and in balloon cells (E). Insert (a) in (C): co-localization (yellow) of UPA (red) with NeuN (green) in a dysplastic neuron. Insert (b) in (C): co-localization (yellow) of uPA (red) with GFAP (green) in reactive astrocytes. Insert (c) in (C): co-localization (yellow) of uPA (red) with HLA-DR (green) in cells of the microglia/ macrophage lineage. Panel (F): uPA IR in cortical tuber of Tuberous Sclerosis Complex (TSC) showing strong expression within the dysplastic cortex in dysplastic neurons (arrow-head) and in blood vessels (arrows). Insert (a) shows expression in giant cells. Insert (b) in (F): co-localization (yellow) of UPA (red) with CD31 (green) in microvascular endothelium. Panel (G): uPA IR in ganglioglioma (GG) showing expression in dysplastic neurons (arrow-heads), blood vessels (arrows) and in tumor astrocytes (insert). Scale bar in (B). (A, C): $400 \mu \mathrm{m}$. (B): $80 \mu \mathrm{m}$. (D, E): $30 \mu \mathrm{m} ;(\mathrm{F}, \mathrm{G}): 100 \mu \mathrm{m}$. For interpretation of the references to color in this figure legend, the reader is referred to the Web version of this article.

which can be in part reproduced in animal models (for review see; Loscher, 2002). The present study shows increased expression of both TPA, UPA and UPAR proteins in HS humans specimens, confirming the prominent and persistent activation of the plasminogen system reported in the animal models of TLE (Lukasiuk et al., 2003; Gorter et al., 2006; Lahtinen et al., 2006). The hippocampal upregulation of the cell surface receptor of UPA (UPAR) observed with western blot analysis, could not be further evaluated at the cellular level, since the antibodies tested, 
A
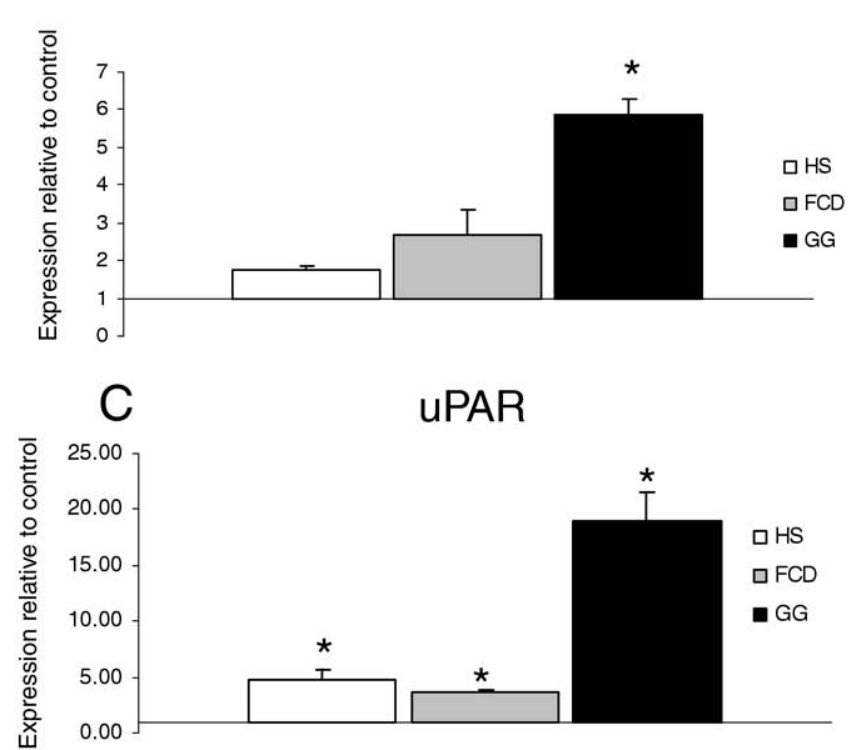

B

UPA

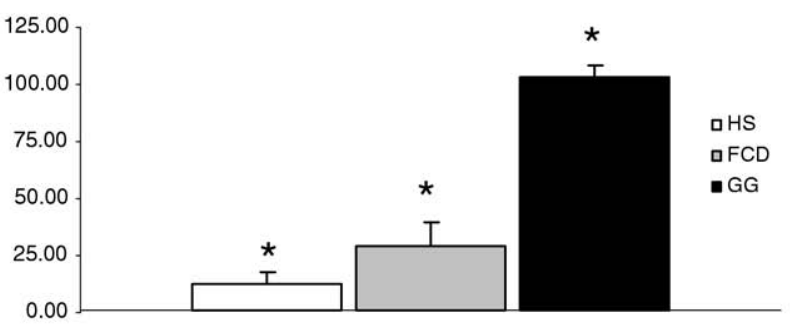

PAI 1

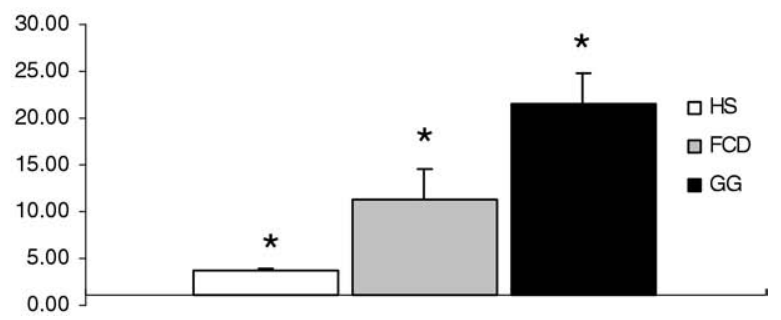

Fig. 8. RT-PCR of tPA, UPA uPAR and plasminogen activator inhibitor type 1 (PAI1) in epileptogenic pathologies. Expression levels were determined in duplicate, corrected for the expression levels of TBP and normalized to control expression levels. Expression levels in hippocampal sclerosis (HS; $n=6$ ) were compared to levels in autopsy control hippocampal specimens $(n=5)$; expression levels in ganglioglioma (GG; $n=6)$ and focal cortical dysplasia (FCD; $n=6$ ) were compared to levels in autopsy control cortical specimens $(n=5)(A)$ : tPA mRNA levels were significantly increased in GG specimens. UPA (B), uPAR (C) and PAI1 (D) mRNA levels were significantly increased in HS, FCD and GG. The error bars represent SEM; statistical significance: ${ }^{*} P<0.05$ compared with control.

were not suitable for immunocytochemistry on paraffinembedded specimens. However, increased expression of both UPA and UPAR mRNA was detected by RT-PCR analysis. A recent report in the post-SE model of TLE shows both astroglial and neuronal expression in the rat hippocampus, suggesting the critical role of UPA/UPAR pathway in epileptogenic tissue remodeling (Lahtinen et al., 2009, 2010).

Although both uPA mRNA and uPA protein are upregulated in epileptogenic tissue, the different expression levels observed could reflect differences in sensitivity between the two methods or be related to post-transcriptional regulation. For instance, a recent study shows weak or no significant correlations between uPA mRNA and protein in breast cancer samples, suggesting posttranscriptional regulation (Biermann et al., 2008). A more recent study confirmed this possibility, demonstrating a microRNA mediated post-transcriptional regulation of UPA through miR-193b (acting as a negative regulator for UPA at the post-transcriptional level; (Li et al., 2009)).

Analysis of the cellular distribution for TPA and UPA showed prominent expression in neuronal cells which is consistent with previous experimental observations demonstrating neuronal expression of tPA and UPA after SE induced seizures (Tsirka et al., 1995; Lahtinen et al., 2006). The presence of a prominent pool of PAs in neurons implies its acute release under pathological conditions associated with increased neuronal activity. Accordingly, a rapid release has been demonstrated for both IPA and
UPA and may critically contribute to increase the amount of PAs in neuronal tissue (Pittman et al., 1989; Gualandris et al., 1996). One crucial mechanism by which tPA can increase neuronal excitability consists of its ability to enhance $\mathrm{N}$-methyl-D-asparte (NMDA) receptor signaling by cleavage of NMDA receptor subunit 1, which constitutes a direct substrate of tPA (Tsirka et al., 1995; Benarroch, 2007). Neuronal PA expression was observed within the different hippocampal sub-fields, including the granule cells of the dentate gyrus. Interestingly, PAs have been shown to modulate neurite outgrowth and to be involved in the reorganization of granule cell axons (mossy fiber sprouting) which is a prominent feature in human TLE (Pittman et al., 1989; Wu et al., 2000; Tsirka, 2002).

In addition to neurons, tPA and UPA were expressed in reactive glial cells, including both astrocytes and activated microglial cells. The large majority of reactive astrocytes in both CA and hilar regions expresses strong PA IR. Regulation of PAs expression has been shown in vitro by different molecules that stimulate glial cell activation/proliferation and are produced within injured human brain tissue (Rogister et al., 1988; Tranque et al., 1992; Faber-Elman et al., 1995; Falcone et al., 1995; Gravanis and Tsirka, 2005; Nakajima et al., 2005). Our data provide the first evidence that astrocytic and microglial expression of PA proteins is present within the sclerotic hippocampus in human TLE. This observation indicates that glial cells within the epileptogenic tissue may represent an important source of PAs. Furthermore, glial PAs may also contribute 
the activation of glial cells (Gravanis and Tsirka, 2005). TPA has been proposed as key regulator of microglia at the site of injury, promoting additional tissue damage (Siao et al., 2003; Gravanis and Tsirka, 2005). In contrast, astrocytes have been suggested to be involved in the neutralization of TPA toxicity, through the uptake of the tPA/ PAl1 complex via an endocytic tPA receptor, the lipoprotein receptor-related protein (LRP) (Fernandez-Monreal et al., 2004). Increased expression of PAI1 mRNA has been observed in both experimental and human TLE (Gorter et al., 2006 and present results). Whether the tPA expression in astrocytes indicates sequestration in the form of an inactive complex with PAI1 in vivo remains to be explored.

Expression of PAs was also increased in blood vessels within the sclerotic hippocampus, indicating that the vascular endothelium represents an additional source of endogenous PAs within the human epileptogenic tissue. Exposure of endothelial cells to angiogenic and/or pro-inflammatory mediators differentially regulates the PA expression in vitro (Gerritsen et al., 1993; Niedbala, 1993; Mandriota et al., 1995; Larsson et al., 2008). Recently, an increase in UPA and UPAR expressing blood vessels has been reported in rat hippocampus after SE induction (Lahtinen et al., 2006, 2009, 2010). The plasminogen system has been shown to play a critical role in angiogenesis (Pepper et al., 1996; Brodsky et al., 2001; Rakic et al., 2003), as well as in the regulation of the BBB permeability (Yepes et al., 2003). Interestingly, alterations of the BBB permeability and angiogenesis have been recently observed in both human and experimental TLE with a positive correlation between the increased vascular permeability and the occurrence of spontaneous seizures in chronic epileptic rats (Rigau et al., 2007; van Vliet et al., 2007; Ravizza et al., 2008). In addition, release of PAs by brain endothelial cells has been suggested to critically regulate monocyte diapedesis through the BBB (Reijerkerk et al., 2008). Thus PAs could indirectly play a pro-epileptogenic role and contribute to the persistent inflammatory reactions observed in human and experimental TLE (Fabene et al., 2008; Ravizza et al., 2008; Vezzani et al., 2008).

\section{Developmental lesions and plasminogen activators}

Focal developmental lesions, including FCD, TSC cortical tubers and glioneuronal tumors (i.e. gangliogliomas) represent another frequent finding in patients with medically intractable TLE (Blumcke et al., 2002; Thom, 2004). These lesions share a number of clinical and pathological features and have been recently included among the MCD characterized by active proliferation and abnormal cell types (Barkovich et al., 2005). Our large-scale gene expression profile analysis recently demonstrated that both tPA and UPA are strongly up-regulated within GG (Aronica et al., 2008). Increased expression was also observed for annexin II, a membrane protein which has been identified as binding partner of tPA, possibly involved in the tPAdependent microglial activation (Siao and Tsirka, 2002). In the present study we confirmed the activation of the plasminogen system in GG, showing increased expression of both IPA and UPA proteins and mRNAs. Increased tPA and UPA protein expression was also detected in FCD. RT-PCR analysis showed up-regulation of UPA and UPAR in both GG and FCD specimens. Similarly to HS specimens, PA IR was observed in both neuronal and glial cells of MCD cases. The large majority of dysmorphic neurons in FCD and TSC specimens, as well as neuronal cells of GG specimens displayed strong UPA and tPA expression, indicating that neurons are a major source of PAs also in developmental lesions. The presence of TPA within these highly epileptogenic lesions may exacerbate neuronal excitability, increasing NMDA receptor signaling. Interestingly, both dysplastic neurons and neuronal cells in GG specimens contain high levels of NMDA receptor subunit proteins (Ying et al., 1999; Aronica et al., 2001a,c). The prominent neuronal expression of PAs in MCD is also interesting considering the increasing evidence that indicates a crucial role for the plasminogen system during brain development (Zhang et al., 2005; Royer-Zemmour et al., 2008). Results obtained using mice lacking the tPA gene indicate a role for IPA in facilitating neuronal migration (Seeds et al., 1999), whereas selective alteration of the distribution of cortical interneurons have been reported in mice lacking the UPAR (Powell et al., 2003; Eagleson et al., 2005). Thus, the induction of PA proteins, producing changes in extracellular matrix and activation of matrix metalloproteinases (Irigoyen et al., 1999; Dityatev and Fellin, 2008) could contribute to the abnormal morphology of dysplastic cells and their abnormal positioning within the dysplastic cortex. Moreover, increasing evidence indicates a critical role for UPAR signaling, independently of UPAmediated proteolysis (Smith and Marshall, 2010). Recently new UPA ligands have been detected, such as the SRPX2 (Sushi-Repeat Protein, X-linked 2). Interestingly, a mutation in SRPX2 is associated with Rolandic epilepsy and bilateral perisylvian polymicrogyria and leads to a gain of affinity of SRPX2 with UPAR (Royer-Zemmour et al., 2008). In addition, considerable evidence indicates that integrins, a major family of extracellular matrix (ECM) receptors (such as $\beta 1$ and $\beta 3$ integrins) represent the most important transmembrane receptors associated with UPAR signalling (reviewed in (Smith and Marshall, 2010)). Several genes associated with cell adhesion, including integrins, are up-regulated in cortical tubers (Boer et al., 2009).

Expression of TPA and UPA was also observed in balloon cells in FCD and giant cells in TSC specimens. The presence of PAs in balloon/giant cells may reflect the immature phenotype of these cells (Cepeda et al., 2003; Alonso-Nanclares et al., 2005; Cepeda et al., 2005; Kalderon et al., 1990). Furthermore, analysis of tPA and UPA cellular distribution in MCD demonstrated both astroglial and microglial cells IR, supporting the contribution of these cells to the amount of PAs that is present in these lesions, as well as the potential role of PAs in glial activation (Gravanis and Tsirka, 2005). The large majority of reactive astrocytes in FCD and TSC, as well as tumor astrocytes in GG, expressed tPA and UPA. Expression of PAs was also increased in blood vessels within the different developmental lesions studied. Interestingly, alterations of the BBB permeability and prominent inflammatory reactions have 
also been observed in focal MCD (Aronica et al., 2005, 2007; Boer et al., 2006, 2008; Ravizza et al., 2006).

Concerning the expression patterns of PAs in glial tumors, increased levels of UPA have been observed in high-grade gliomas, whereas the data on the expression of tPA are still controversial (for review see; Levicar et al., 2003). In particular attention has been focused on their role in tumor invasion and angiogenesis in high grade tumors (Yamamoto et al., 1994; Levicar et al., 2003). Our observations indicate that induction of the plasminogen system may also occur in low-grade glioneuronal tumors, such as GG. Although a rapid induction of PAs can be triggered in experimental epilepsy models (Lukasiuk et al., 2003; Gorter et al., 2006; Lahtinen et al., 2006), seizures alone cannot account for the increased PA expression in these developmental lesions since the analysis of the histologically normal perilesional cortex showed a pattern of neuronal IR similar to that observed in control cortex. However, recent evidence suggests that molecular and functional alterations in the perilesional region, may also contribute to the epileptogenicity of focal MCD (Wong, 2008). Thus, evaluation of a larger number of samples, including also areas of electrocortico-graphically defined perilesional epileptogenic regions, is required to exclude a possible occurrence of perilesional tPA and uPA changes.

\section{CONCLUSION}

In summary, our findings demonstrate that activation of the plasminogen system, as exemplified by increased expression of tPA and UPA, indeed occurs in human focal chronic refractory epilepsy, confirming the studies performed in experimental models of TLE. The chronic expression of PAs together with the up-regulation of UPAR might contribute to the mechanisms underlying the epileptogenicity of focal lesions, through direct modulation of neuronal activity or, indirectly, through regulation of the inflammatory response and/or epiletogenic tissue remodeling. Several mechanisms are possibly involved, including a direct regulation of neuronal excitability via NMDA receptors (Tsirka et al., 1995; Benarroch, 2007). Additionally, both tPA and uPA may contribute to the disruption of bloodbrain barrier integrity and amplification of inflammatory infiltrates (Lo et al., 2002; Del Rosso et al., 2008), which have been recently shown to play a critical role in chronic refractory epilepsy (Vezzani and Granata, 2005; Oby and Janigro, 2006). Finally we have to consider the key role of the PA system in the complex tissue remodeling that occurs during epileptogenesis, such as axonal reorganization, angiogenesis and astrogliosis (Dityatev and Fellin, 2008). Further research, particularly using different animal models, including models of MCD, might help to develop anti-epileptic treatments that target specific components of PA/UPAR-mediated signaling.

Acknowledgments-We are grateful to J.T. van Heteren for her technical help. This work has been supported by National Epilepsy Fund, NEF 09-05 (EA); EU FP7 project NeuroGlia, Grant Agreement $N^{\circ} 202167$ and Stichting Michelle M06.011, M07.016(EA, $A M Y)$.

\section{REFERENCES}

Alfano D, Franco P, Vocca I, Gambi N, Pisa V, Mancini A, Caputi M, Carriero MV, laccarino I, Stoppelli MP (2005) The urokinase plasminogen activator and its receptor: role in cell growth and apoptosis. [see comment]. Thromb Haemost 93:205-211.

Alonso-Nanclares L, Garbelli R, Sola RG, Pastor J, Tassi L, Spreafico $\mathrm{R}$, DeFelipe J (2005) Microanatomy of the dysplastic neocortex from epileptic patients. Brain 128:158-173.

Aronica E, Boer K, Becker A, Redeker S, Spliet WG, van Rijen PC, Wittink F, Breit T, Wadman WJ, Lopes da Silva FH, Troost D, Gorter JA (2008) Gene expression profile analysis of epilepsyassociated gangliogliomas. Neuroscience 151:272-292.

Aronica E, Boer K, van Vliet EA, Baayen JC, Redeker S, Spliet WGM, Lopes da Silva FH, Wadman WJ, Troost D, Gorter JA (2007) Complement activation in experimental and human temporal lobe epilepsy. Neurobiol Dis 26:497-511.

Aronica E, Catania MV, Geurts J, Yankaya B, Troost B (2001a) Immunohistochemical localization of Group I and II metabotropic glutamate receptors in control and ALS human spinal cord: upregulation in reactive astrocytes. Neuroscience 105:509-520.

Aronica E, Gorter JA, Ramkema M, Redeker S, Ozbas-Gerceker F, van Vliet EA, Scheffer GL, Scheper RJ, van der Valk P, Baayen JC, Troost D (2004) Expression and cellular distribution of multidrug resistance-related proteins in the hippocampus of patients with mesial temporal lobe epilepsy. Epilepsia 45:441-451.

Aronica E, Gorter JA, Redeker S, Ramkema M, Spliet WG, van Rijen PC, Leenstra S, Troost D (2005) Distribution, characterization and clinical significance of microglia in glioneuronal tumours from patients with chronic intractable epilepsy. Neuropathol Appl Neurobiol $31: 280-291$.

Aronica E, Leenstra S, Jansen GH, van Veelen CW, Yankaya B, Troost D (2001b) Expression of brain-derived neurotrophic factor and tyrosine kinase $B$ receptor proteins in glioneuronal tumors from patients with intractable epilepsy: colocalization with N-methyl-Daspartic acid receptor. Acta Neuropathol 101:383-392.

Aronica EM, Leenstra S, Jansen G, van Veelen CW, Yankaya B, Troost D (2001c) Expression of BDNF and tyrosine kinase B (TrkB) receptor proteins in glioneuronal tumors from patients with intractable epilepsy: colocalization with NMDA receptor. Acta Neuropathol 101:383-392.

Barkovich AJ, Kuzniecky RI, Jackson GD, Guerrini R, Dobyns WB (2005) A developmental and genetic classification for malformations of cortical development. Neurology 65:1873-1887.

Benarroch EE (2007) Tissue plasminogen activator: beyond thrombolysis. Neurology 69:799-802.

Biermann JC, Holzscheiter L, Kotzsch M, Luther T, Kiechle-Bahat M, Sweep FC, Span PN, Schmitt M, Magdolen V (2008) Quantitative RT-PCR assays for the determination of urokinase-type plasminogen activator and plasminogen activator inhibitor type 1 mRNA in primary tumor tissue of breast cancer patients: comparison to antigen quantification by ELISA. Int J Mol Med 21:251-259.

Blumcke I, Pauli E, Clusmann H, Schramm J, Becker A, Elger C, Merschhemke $M$, Meencke HJ, Lehmann $T$, von Deimling $A$, Scheiwe C, Zentner J, Volk B, Romstock J, Stefan H, Hildebrandt M (2007) A new clinico-pathological classification system for mesial temporal sclerosis. Acta Neuropathol 113:235-244.

Blumcke I, Thom M, Wiestler OD (2002) Ammon's horn sclerosis: a maldevelopmental disorder associated with temporal lobe epilepsy. Brain Pathol 12:199-211.

Boer K, Crino PB, Gorter JA, Nellist M, Jansen FE, Spliet WG, van Rijen PC, Wittink F, Breit T, Troost D, Wadman WJ, Aronica E (2009) Gene expression analysis of tuberous sclerosis complex cortical tubers reveals increased expression of adhesion and inflammatory factors. Brain Pathol 2009, Oct 8; [Epub ahead of print]; doi:10.1111/j.1750-3639.2009.00341.

Boer K, Jansen K, Nellist M, Redeker M, van den Ouweland AMW, Spliet WGM, van Nieuwenhuizen O, Troost D, Crino PB, Aronica E 
(2008) Inflammatory processes in cortical tubers and subependymal giant cell tumors of tuberous sclerosis complex. Epilepsy Res 78:7-21.

Boer K, Spliet WG, van Rijen PC, Redeker S, Troost D, Aronica E (2006) Evidence of activated microglia in focal cortical dysplasia. J Neuroimmunol 173:188-195.

Brodsky S, Chen J, Lee A, Akassoglou K, Norman J, Goligorsky MS (2001) Plasmin-dependent and -independent effects of plasminogen activators and inhibitor- 1 on ex vivo angiogenesis. Am J Physiol Heart Circ Physiol 281:H1784-H1792.

Carmeliet P, Collen D (1995) Gene targeting and gene transfer studies of the biological role of the plasminogen/plasmin system. Thromb Haemost 74:429-436.

Cepeda C, Andre VM, Vinters HV, Levine MS, Mathern GW (2005) Are cytomegalic neurons and balloon cells generators of epileptic activity in pediatric cortical dysplasia? Epilepsia 46:82-88.

Cepeda C, Hurst RS, Flores-Hernandez J, Hernandez-Echeagaray E, Klapstein GJ, Boylan MK, Calvert CR, Jocoy EL, Nguyen OK, Andre VM, Vinters HV, Ariano MA, Levine MS, Mathern GW (2003) Morphological and electrophysiological characterization of abnormal cell types in pediatric cortical dysplasia. J Neurosci Res 72: 472-486.

Collen D (1999) The plasminogen (fibrinolytic) system. Thromb Haemost 82:259-270.

Del Rosso M, Fibbi G, Pucci M, Margheri F, Serrati S (2008) The plasminogen activation system in inflammation. Front Biosci 13:4667-4686.

Dent MA, Sumi Y, Morris RJ, Seeley PJ (1993) Urokinase-type plasminogen activator expression by neurons and oligodendrocytes during process outgrowth in developing rat brain. Eur $\mathrm{J}$ Neurosci 5:633-647.

Dityatev A, Fellin T (2008) Extracellular matrix in plasticity and epileptogenesis. Neuron Glia Biol 4:235-247.

Eagleson KL, Bonnin A, Levitt P (2005) Region- and age-specific deficits in gamma-aminobutyric acidergic neuron development in the telencephalon of the uPAR(-/-) mouse. J Comp Neurol 489: 449-466.

Fabbro S, Seeds NW (2009) Plasminogen activator activity is inhibited while neuroserpin is up-regulated in the Alzheimer disease brain. J Neurochem 109:303-315.

Fabene PF, Navarro MG, Martinello M, Rossi B, Merigo F, Ottoboni L, Bach S, Angiari S, Benati D, Chakir A, Zanetti L, Schio F, Osculati A, Marzola P, Nicolato E, Homeister JW, Xia L, Lowe JB, McEver RP, Osculati F, Sbarbati A, Butcher EC, Constantin G (2008) A role for leukocyte-endothelial adhesion mechanisms in epilepsy. [see comment]. Nat Med 14:1377-1383.

Faber-Elman A, Miskin R, Schwartz M (1995) Components of the plasminogen activator system in astrocytes are modulated by tumor necrosis factor-alpha and interleukin-1beta through similar signal transduction pathways. J Neurochem 65:1524-1535.

Falcone DJ, McCaffrey TA, Mathew J, McAdam K, Borth W (1995) THP-1 macrophage membrane-bound plasmin activity is up-regulated by transforming growth factor-beta 1 via increased expression of urokinase and the urokinase receptor. J Cell Physiol 164:334-343.

Fernandez-Monreal M, Lopez-Atalaya JP, Benchenane K, Leveille F, Cacquevel M, Plawinski L, MacKenzie ET, Bu G, Buisson A, Vivien D (2004) Is tissue-type plasminogen activator a neuromodulator? Mol Cell Neurosci 25:594-601.

Gerritsen ME, Niedbala MJ, Szczepanski A, Carley WW (1993) Cytokine activation of human macro- and microvessel-derived endothelial cells. Blood Cells 19:325-339; discussion 340-322.

Gomez M, Sampson J, Whittemore V (1999) The tuberous sclerosis complex. Oxford: Oxford University Press.

Gorter JA, Van Vliet E, Aronica E, Rauwerda H, Breit T, Lopes da Silva FH, Wadman WJ (2006) Potential new antiepileptogenic targets indicated by microarray analysis in a rat model for temporal lobe epilepsy. J Neurosci 26:11083-11110.
Gorter JA, Van Vliet E, Rauwerda H, Breit T, van Schaik L, Vreugdenhil E, Redeker S, Aronica E, Lopes da Silva FH, Wadman WJ (2007) Dynamic changes of proteases and protease inhibitors revealed by microarray analysis in CA3 and temporal lobe during epileptogenesis in the rat. Epilepsia 40:1-12.

Gravanis I, Tsirka SE (2005) Tissue plasminogen activator and glial function. Glia 49:177-183.

Gualandris A, Jones TE, Strickland S, Tsirka SE (1996) Membrane depolarization induces calcium-dependent secretion of tissue plasminogen activator. J Neurosci 16:2220-2225.

Gveric D, Hanemaaijer R, Newcombe J, van Lent NA, Sier CF, Cuzner ML (2001) Plasminogen activators in multiple sclerosis lesions: implications for the inflammatory response and axonal damage. Brain 124:1978-1988.

Irigoyen JP, Munoz-Canoves P, Montero L, Koziczak M, Nagamine $\mathrm{Y}$ (1999) The plasminogen activator system: biology and regulation. Cell Mol Life Sci 56:104-132.

Kalderon N, Ahonen K, Fedoroff S (1990) Developmental transition in plasticity properties of differentiating astrocytes: age-related biochemical profile of plasminogen activators in astroglial cultures. Glia 3:413-426.

Lahtinen L, Lukasiuk K, Pitkanen A (2006) Increased expression and activity of urokinase-type plasminogen activator during epileptogenesis. Eur J Neurosci 24:1935-1945.

Lahtinen L, Huusko N, Myohanen H, Lehtivarjo AK, Pellinen R, Turunen MP, Yla-Herttuala S, Pirinen E, Pitkanen A (2009) Expression of urokinase-type plasminogen activator receptor is increased during epileptogenesis in the rat hippocampus. Neuroscience 163:316-328.

Lahtinen L, Ndode-Ekane XE, Barinka F, Akamine Y, Esmaeili MH, Rantala J, Pitkänen A (2010) Urokinase-type plasminogen activator regulates neurodegeneration and neurogenesis but not vascular changes in the mouse hippocampus after status epilepticus. Neurobiol Dis 37:692-703.

Larsson P, Ulfhammer E, Karlsson L, Bokarewa M, Wahlander K, Jern S (2008) Effects of IL-1beta and IL-6 on tissue-type plasminogen activator expression in vascular endothelial cells. Thromb Res 123:342-351.

Levicar N, Nuttall RK, Lah TT (2003) Proteases in brain tumour progression. [erratum appears in Acta Neurochir (Wien). 2003 Nov; 145(11):1023 Note: Nutall R K [corrected to Nuttall R K]]. Acta Neurochirurgica 145:825-838.

Li XF, Yan PJ, Shao ZM (2009) Downregulation of Mir-193b contributes to enhance urokinase-type plasminogen activator (UPA) expression and tumor progression and invasion in human breast cancer. Oncogene 28:3937-3948.

Lijnen HR, Nelles L, Van Hoef B, Demarsin E, Collen D (1988) Characterization of a chimeric plasminogen activator consisting of amino acids 1 to 274 of tissue-type plasminogen activator and amino acids 138 to 411 of single-chain urokinase-type plasminogen activator. J Biol Chem 263:19083-19091.

Lo EH, Wang X, Cuzner ML (2002) Extracellular proteolysis in brain injury and inflammation: role for plasminogen activators and matrix metalloproteinases. J Neurosci Res 69:1-9.

Loscher W (2002) Animal models of drug-resistant epilepsy. Novartis Found Symp 243:149-159; discussion 159-166.

Louis DN, Ohgaki H, Wiestler OD, Cavanee WK (2007) WHO classification of tumours of the central nervous system. Lyon: IARC.

Lukasiuk K, Kontula L, Pitkanen A (2003) cDNA profiling of epileptogenesis in the rat brain. Eur J Neurosci 17:271-279.

Mandriota SJ, Seghezzi G, Vassalli JD, Ferrara N, Wasi S, Mazzieri R, Mignatti P, Pepper MS (1995) Vascular endothelial growth factor increases urokinase receptor expression in vascular endothelial cells. J Biol Chem 270:9709-9716.

Masos T, Miskin R (1996) Localization of urokinase-type plasminogen activator mRNA in the adult mouse brain. Brain Res Mol Brain Res 35:139-148. 
Maupas-Schwalm F, Auge N, Robinet C, Cambus JP, Parsons SJ, Salvayre R, Negre-Salvayre A (2004) The sphingomyelin/ceramide pathway is involved in ERK1/2 phosphorylation, cell proliferation, and uPAR overexpression induced by tissue-type plasminogen activator. FASEB J 18:1398-1400.

Nakajima K, Tohyama Y, Kurihara T, Kohsaka S (2005) Enhancement of urokinase-type plasminogen activator (UPA) secretion, but not that of substrate plasminogen (PGn), by rat microglia stimulated with neuronal conditioned medium. Neurosci Lett 378:13-17.

Niedbala MJ (1993) Cytokine regulation of endothelial cell extracellular proteolysis. Agents Actions Suppl 42:179-193.

Oby E, Janigro D (2006) The blood-brain barrier and epilepsy. Epilepsia 47:1761-1774.

Palmini A, Najm I, Avanzini G, Babb T, Guerrini R, Foldvary-Schaefer N, Jackson G, Luders HO, Prayson R, Spreafico R, Vinters HV (2004) Terminology and classification of the cortical dysplasias. Neurology 62:S2-S8.

Pawlak R, Strickland S (2002) Tissue plasminogen activator and seizures: a clot-buster's secret life. [comment]. J Clin Invest 109: $1529-1531$.

Pepper MS, Montesano R, Mandriota SJ, Orci L, Vassalli JD (1996) Angiogenesis: a paradigm for balanced extracellular proteolysis during cell migration and morphogenesis. Enzyme Protein 49: $138-162$.

Pittman RN, Ivins JK, Buettner HM (1989) Neuronal plasminogen activators: cell surface binding sites and involvement in neurite outgrowth. J Neurosci 9:4269-4286.

Powell EM, Campbell DB, Stanwood GD, Davis C, Noebels JL, Levitt P (2003) Genetic disruption of cortical interneuron development causes region- and GABA cell type-specific deficits, epilepsy, and behavioral dysfunction. J Neurosci 23:622-631.

Rakic JM, Maillard C, Jost M, Bajou K, Masson V, Devy L, Lambert V, Foidart JM, Noel A (2003) Role of plasminogen activator-plasmin system in tumor angiogenesis. Cell Mol Life Sci 60:463-473.

Ramakers C, Ruijter JM, Deprez RH, Moorman AF (2003) Assumption-free analysis of quantitative real-time polymerase chain reaction (PCR) data. Neurosci Lett 339:62-66.

Ravizza T, Boer K, Redeker S, Spliet WG, van Rijen PC, Troost D, Vezzani A, Aronica E (2006) The IL-1beta system in epilepsyassociated malformations of cortical development. Neurobiol Dis 24:128-143.

Ravizza T, Gagliardi B, Noe F, Boer K, Aronica E, Vezzani A (2008) Innate and adaptive immune mechanisms during epileptogenesis and spontaneous seizures: evidence from experimental models and human temporal lobe epilepsy. Neurobiol Dis 29:142-160.

Reijerkerk A, Kooij G, van der Pol SM, Leyen T, van Het Hof B, Couraud PO, Vivien D, Dijkstra CD, de Vries HE (2008) Tissuetype plasminogen activator is a regulator of monocyte diapedesis through the brain endothelial barrier. J Immunol 181:3567-3574.

Rigau V, Morin M, Rousset MC, de Bock F, Lebrun A, Coubes P, Picot MC, Baldy-Moulinier M, Bockaert J, Crespel A, Lerner-Natoli M (2007) Angiogenesis is associated with blood-brain barrier permeability in temporal lobe epilepsy. Brain 130:1942-1956.

Rogister B, Leprince P, Pettmann B, Labourdette G, Sensenbrenner M, Moonen G (1988) Brain basic fibroblast growth factor stimulates the release of plasminogen activators by newborn rat cultured astroglial cells. Neurosci Lett 91:321-326.

Royer-Zemmour B, Ponsole-Lenfant M, Gara H, Roll P, Leveque C, Massacrier A, Ferracci G, Cillario J, Robaglia-Schlupp A, Vincentelli R, Cau P, Szepetowski P (2008) Epileptic and developmental disorders of the speech cortex: ligand/receptor interaction of wildtype and mutant SRPX2 with the plasminogen activator receptor uPAR. Hum Mol Genet 17:3617-3630.

Schmitt M, Chucholowski N, Busch E, Hellmann D, Wagner B, Goretzki L, Janicke F, Gunzler WA, Graeff H (1991) Fluorescent probes as tools to assess the receptor for the urokinase-type plasminogen activator on tumor cells. Semin Thromb Hemost 17:291-302.
Seeds NW, Basham ME, Haffke SP (1999) Neuronal migration is retarded in mice lacking the tissue plasminogen activator gene. Proc Natl Acad Sci U S A 96:14118-14123.

Siao CJ, Fernandez SR, Tsirka SE (2003) Cell type-specific roles for tissue plasminogen activator released by neurons or microglia after excitotoxic injury. J Neurosci 23:3234-3242.

Siao CJ, Tsirka SE (2002) Tissue plasminogen activator mediates microglial activation via its finger domain through annexin II. J Neurosci 22:3352-3358.

Smith HW, Marshall CJ (2010) Regulation of cell signalling by uPAR. Nat Rev Mol Cell Biol 11:23-36.

Smith PK, Krohn RI, Hermanson GT, Mallia AK, Gartner FH, Provenzano MD, Fujimoto EK, Goeke NM, Olson BJ, Klenk DC (1985) Measurement of protein using bicinchoninic acid. Anal Biochem 150:76-85.

Teesalu T, Kulla A, Asser T, Koskiniemi M, Vaheri A (2002) Tissue plasminogen activator as a key effector in neurobiology and neuropathology. Biochem Soc Trans 30:183-189.

Teesalu T, Kulla A, Simisker A, Siren V, Lawrence DA, Asser T, Vaheri A (2004) Tissue plasminogen activator and neuroserpin are widely expressed in the human central nervous system. Thromb Haemost 92:358-368

Thom M (2004) Recent advances in the neuropathology of focal lesions in epilepsy. Expert Rev Neurother 4:973-984.

Tranque P, Robbins R, Naftolin F, Andrade-Gordon P (1992) Regulation of plasminogen activators and type-1 plasminogen activator inhibitor by cyclic AMP and phorbol ester in rat astrocytes. Glia 6:163-171.

Tsirka SE (2002) Tissue plasminogen activator as a modulator of neuronal survival and function. Biochem Soc Trans 30:222-225.

Tsirka SE, Gualandris A, Amaral DG, Strickland S (1995) Excitotoxininduced neuronal degeneration and seizure are mediated by tissue plasminogen activator. Nature 377:340-344.

Tucker HM, Kihiko-Ehmann M, Estus S (2002) Urokinase-type plasminogen activator inhibits amyloid-beta neurotoxicity and fibrillogenesis via plasminogen. J Neurosci Res 70:249-255.

van Vliet EA, da Costa Araújo S, Redeker S, van Schaik R, Aronica E, Gorter JA (2007) Long-lasting increased permeability of the bloodbrain barrier may contribute to seizure progression in temporal lobe epilepsy. Brain 130:521-534.

Vandeputte DA, Troost D, Leenstra S, ljlst-Keizers H, Ramkema M, Bosch DA, Baas F, Das NK, Aronica E (2002) Expression and distribution of id helix-loop-helix proteins in human astrocytic tumors. Glia 38:329-338.

Vezzani A, Granata T (2005) Brain inflammation in epilepsy: experimental and clinical evidence. Epilepsia 46:1724-1743.

Vezzani A, Ravizza T, Balosso S, Aronica E (2008) Glia as a source of cytokines: implications for neuronal excitability and survival. Epilepsia 49(Suppl 2):24-32.

Wagner SN, Atkinson MJ, Wagner C, Hofler H, Schmitt M, Wilhelm O (1996) Sites of urokinase-type plasminogen activator expression and distribution of its receptor in the normal human kidney. Histochem Cell Biol 105:53-60.

Wieser HG (2004) ILAE Commission Report. Mesial temporal lobe epilepsy with hippocampal sclerosis. Epilepsia 45:695-714.

Wong M (2008) Mechanisms of epileptogenesis in tuberous sclerosis complex and related malformations of cortical development with abnormal glioneuronal proliferation. Epilepsia 49:8-21.

Wu YP, Siao CJ, Lu W, Sung TC, Frohman MA, Milev P, Bugge TH, Degen JL, Levine JM, Margolis RU, Tsirka SE (2000) The tissue plasminogen activator (tPA)/ plasmin extracellular proteolytic system regulates seizureinduced hippocampal mossy fiber outgrowth through a proteoglycan substrate. J Cell Biol 148:1295-1304.

Wyler AR, Dohan C, Schweitzer JB, Berry AD III (1992) A grading system for mesial temporal pathology (hippocampal sclerosis) from anterior temporal lobectomy. J Epilepsy 5:220-225.

Yamamoto M, Sawaya R, Mohanam S, Bindal AK, Bruner JM, Oka K, Rao VH, Tomonaga M, Nicolson GL, Rao JS (1994) Expression 
and localization of urokinase-type plasminogen activator in human astrocytomas in vivo. Cancer Res 54:3656-3661.

Yepes M, Sandkvist M, Moore EG, Bugge TH, Strickland DK, Lawrence DA (2003) Tissue-type plasminogen activator induces opening of the blood-brain barrier via the LDL receptor-related protein. $\mathrm{J}$ Clin Invest 112:1533-1540.
Ying Z, Babb TL, Mikuni N, Najm I, Drazba J, Bingaman W (1999) Selective coexpression of NMDAR2A/B and NMDAR1 subunit proteins in dysplastic neurons of human epileptic cortex. Exp Neurol 159:409-418.

Zhang Y, Pothakos K, Tsirka SA (2005) Extracellular proteases: biological and behavioral roles in the mammalian central nervous system. Curr Top Dev Biol 66:161-188.

(Accepted 19 February 2010)

(Available online 26 February 2010) 